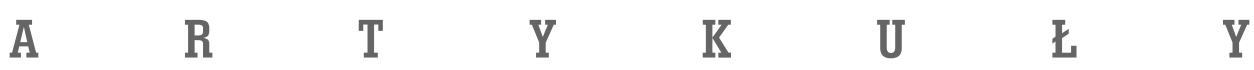

Jarosław Rubacha

Uniwersytet Warmińsko-Mazurski w Olsztynie

\title{
Bułgarzy i Bułgaria w ostatniej ćwierci wieku XIX w publikacjach Jana Grzegorzewskiego (polityka wewnętrzna, polityka zagraniczna)
}

Zarys treści: Jan Grzegorzewski, wybitny polski slawista i orientalista, odbył na przełomie XIX i XX w. kilka podróży po Bałkanach. W ich trakcie dokonał wnikliwych obserwacji miejscowych stosunków politycznych, z których wnioski zawarł w kilku opublikowanych na przełomie stuleci książkach i artykułach. Ważne miejsce w jego pracy badawczej zajmowała Bułgaria. Niniejszy artykuł jest prezentacją obrazu tego kraju, postrzeganego przez autora przez pryzmat podjętych w jego pracach wątków - polityki wewnętrznej i zagranicznej.

Outline of content: Jan Grzegorzewski, an outstanding Polish Slavic philologist and Orientalists, undertook several voyages throughout the Balkans at the turn of the $20^{\text {th }}$ century. During those trips he made careful and detailed observations of local political relations, and published his conclusions in several books and articles published at the end of the $19^{\text {th }}$ and early $20^{\text {th }}$ century. Special place in his research work was occupied by Bulgaria. The purpose of the article is to present the image of this country as seen by Grzegorzewski through the prism of central themes brought up in his writings - internal and foreign policy.

Słowa kluczowe: Jan Grzegorzewski, Bułgaria w XIX w., polityka wewnętrzna, polityka zagraniczna, wojna serbsko-bułgarska 1885

Keywords: Jan Grzegorzewski, Bulgaria in XIX century, Bulgarian internal policy, Bulgarian foreign policy, Serbo-Bulgarian War of 1885

Druga połowa XIX w., a zwłaszcza ostatnie jego dwudziestopięciolecie to okres niezwykle głębokich przemian w Europie. Objęły one niemal wszystkie dziedziny życia społecznego, a częścią Starego Kontynentu, w której procesy te nabrały szczególnego tempa, były Bałkany. Nałożenie się na tej stosunkowo niewielkiej przestrzeni czynników natury politycznej, zarówno w kontekście wewnętrznym, jak i zewnętrznym, społecznych, etnicznych, kulturowych sprawiło, że już w połowie 
XIX stulecia Półwysep Bałkański zaczęto nazywać „beczką prochu”, której wybuch mógł trwale destabilizować sytuację w Europie. W kwestii tej szczególną rolę odgrywali Bułgarzy, którzy, wykazując dużą konsekwencję w dążeniu do narodowych celów, a jednocześnie górując pod względem ludnościowym, a następnie także terytorialnym nad sąsiednimi narodami, bardzo szybko stali się kluczowym elementem regionalnej i ogólnoeuropejskiej polityki. Te dynamicznie zachodzące procesy $\mathrm{z}$ dużym zainteresowaniem obserwowali nie tylko politycy i dyplomaci, ale także szerokie europejskie kręgi społeczne, informowane przez korespondentów i publicystów ówczesnych gazet i czasopism.

Jednym $\mathrm{z}$ nich był wybitny polski etnograf, slawista i orientalista Jan Grzegorzewski ${ }^{1}$, który jako korespondent wojenny polskich i francuskich dzienników miał okazję poznać Bałkany podczas podróży do Konstantynopola w 1877 r. Duże wrażenie, jakie wywarła na nim ta część Europy, wkrótce potem przerodziło się w swego rodzaju fascynację, która skłaniała go do kolejnych wyjazdów na Bałkany w następnych latach, a ostatecznie zachęciła do zamieszkania w $1904 \mathrm{r}$. w darzonej przez niego szczególną sympatią Bułgarii. Efektem tych licznych podróży oraz ponaddziesięcioletniego pobytu w Sofii były publikacje książkowe i artykuły poświęcone tematyce bułgarskiej ${ }^{2}$, oparte głównie na wynikach własnych, dogłębnych obserwacji. Jednocześnie w trakcie ich tworzenia Grzegorzewski wykorzystywał także wspomnienia i pamiętniki, doniesienia prasowe oraz ówczesne opracowania i monografie ${ }^{3}$. Tym samym jego prace prezentujące bułgarską scenę polityczną, działania na arenie międzynarodowej oraz toczącą się w tej części kontynentu rywalizację wielkich mocarstw o strefy wpływów miały i mają również obecnie duży walor poznawczy, chociaż często prezentują jego subiektywny punkt widzenia na poszczególne kwestie.

Analizując twórczość Jana Grzegorzewskiego poświęconą wyżej wskazanym zagadnieniom, nie trudno odnieść wrażenia, że szczególnym jego zainteresowaniem cieszyły się kwestie związane z bułgarskim systemem politycznym, który często prezentował na tle oficjalnych i zakulisowych działań wielkich mocarstw, a zwłaszcza Rosji.

${ }^{1}$ Szczegółowy życiorys Jana Grzegorzewskiego i jego dorobek naukowy w: J. Rubacha, Bułgarzy i Bułgaria w ostatniej ćwierci wieku XIX w publikacjach Jana Grzegorzewskiego (kultura, ludność, gospodarka), „Studia z Dziejów Rosji i Europy Południowo-Wschodniej” 51 (2016), z. 1, s. $24-27,47$.

2 J. Grzegorzewski, Rok przewrotów (Bułgarya 1885/86), Lwów 1900; idem, Dragan Cankow, „Świat Słowiański” 7 (1911), nr 1 (77); idem, Stronnictwa bułgarskie za Aleksandra Battenberga, ibidem, nr 2 (80-81); idem, Siedmiomiesięczna walka o samoistność Bułgaryi, „Świat Słowiański” 8 (1912), $\mathrm{nr} 1$ (87); nr 1 (88); nr 1 (89); idem, Stronnictwa bułgarskie po przewrotach, ibidem, nr 2 (95); nr 2 (96).

3 Były to m.in.: A.G. Drandar, La Bulgarie sous le prince Ferdinand, 1887-1908, Bruxelles 1909; idem, Les événements politiques en Bulgarie, depuis 1876 jusqu'à nos jours, Bruxelles / Paris 1896; Ю. Карцов, Семь лет на Ближнем Востоке 1879-1886. Воспоминания политические и личные, Санкт-Петербург 1906; С. Радев, Строителите на съвременна България, т. 1-2, София 1911. 
Opanowanie przez Turków ziem bułgarskich pod koniec XIV w. pociągnęło za sobą głębokie i wieloaspektowe następstwa. W kontekście Bułgarii agresja obcych etnicznie i kulturowo najeźdźców nie tylko przerwała rozwój dynamicznie rozwijającego się organizmu państwowego i przyniosła poważne zniszczenia, ale przede wszystkim w znaczący sposób wpłynęła na strukturę społeczną tamtejszej ludności, eliminując miejscowe elity narodowe ${ }^{4}$. Jednocześnie Bułgarzy, będący członkami niższych grup społecznych jako innowiercy, zostali pozbawieni wszelkich praw publicznych i zepchnięci do rangi tzw. raja, czyli taniej siły roboczej ${ }^{5}$. Jakkolwiek $\mathrm{w}$ miarę upływu czasu, a zwłaszcza od lat trzydziestych XIX w., w związku $\mathrm{z}$ wkroczeniem Turcji w okres reform nazywany tanzymatem ${ }^{6}$, status majątkowy części bułgarskiego społeczeństwa zaczął się powoli zmieniać, co prowadziło do wykrystalizowania się grupy bogatego chłopstwa zwanego czorbadży, jego ogólne położenie nie uległo zasadniczej zmianie aż do 1878 r. Niemniej wzrost zamożności otworzył możliwości kształcenia się coraz większemu gronu Bułgarów poza granicami Turcji, a zarazem, za ich pośrednictwem, przenoszenie zaobserwowanych tam wzorców i poznanych idei ${ }^{7}$. Tym samym rosło wśród społeczeństwa poczucie tożsamości narodowej i nasilał się opór wobec okupanta, a Bułgarzy aktywniej zaczęli podejmować próby zrzucenia obcego panowania. Warto jednak podkreślić, że do 1878 r. proces ten przebiegał relatywnie wolno, a u progu niepodległości Bułgaria dysponowała zaledwie garstką ludzi przygotowanych do pełnienia służby publicznej zarówno w lokalnym, jak i ogólnopaństwowym wymiarze ${ }^{8}$.

Sytuacja ta stała się poważnym problemem po uzyskaniu niezależności. Zgodnie $\mathrm{z}$ postanowieniami kongresu berlińskiego, stojący na czele zarządzającej ziemiami bułgarskimi po wojnie z Turcją tymczasowej administracji rosyjskiej Aleksander Dondukow-Korsakow podjął decyzję o zwołaniu do Wielkiego Tyrnowa Zgromadzenia Ustawodawczego, którego celem miało być omówienie i przyjęcie pierwszej w dziejach Bułgarii konstytucji. Zgromadzenie to - jak pisał Grzegorzewski - w większości „złożone z chłopów i w ogół ludzi rzadko

${ }^{4}$ J. Grzegorzewski, Rok przewrotów..., s. 34.

${ }^{5}$ Ibidem, s. 35.

6 T. Wituch, Tureckie przemiany. Dzieje Turcji 1878-1923, Warszawa 1980, s. 11-19.

7 K. Murzyński, Serbia i jej przodownictwo, „Niwa” 9 (1880), z. 124, s. 245; J. Grzegorzewski, Stronnictwa bułgarskie po przewrotach..., $\mathrm{nr}$ 2, s. 773. Proces ten obrazowo przedstawił Grzegorzewski, pisząc: „Dawniejszej bojarszczyzny, zakonserwowanej jeszcze w Bośni i Hercegowinie pod muzułmańską postacią begów, śladów tu nie pozostało; władztwem zaś Turków wytworzone w ciągu wieków różne kategorye rajjów uprzywilejowanych, uposażonych t.z. basztyną (ojcowizną) dla usług fachowych państwu ottomańskiemu, ostatecznie rozwiązane tanzimatami reformistycznymi na początku wieku XIX, utonęły ponownie w jednolitej masie reszty rajjów, podrażnionych temiż tanzimatami z jednej strony, erygowaniem samodzielnego egzarchatu z drugiej, agitacyą zewnętrzną z trzeciej i komitetami rewolucynemi w czwartej”, idem, Stronnictwa bułgarskie za Aleksandra Battenberga..., nr 2 (80-81), s. 81.

8 J. Grzegorzewski, Stronnictwa bułgarskie za Aleksandra Battenberga..., s. 82. 
nawet wyszłych ze szkoły początkowej”, , podchodziło do poszczególnych zagadnień niezwykle emocjonalnie, co sprawiało, że toczone dyskusje były bardzo zacięte. Jakkolwiek utrudniało to osiągnięcie konsensusu, jednocześnie kształciło nową klasę polityczną, która już w trakcie obrad skupiła się wokół liderów dwóch antagonistycznie do siebie nastawionych nurtów - liberalnego i konserwatywnego ${ }^{10}$. Na czele pierwszego, zwanego potocznie „młodymi”, stanął Petko Karawełow, a jego najaktywniejszymi współpracownikami stali się Dragan Cankow i Petko Sławejkow. Ugrupowanie to, odwołując się do poglądów zachodnioeuropejskich i rosyjskich środowisk demokratycznych i rewolucyjnych, reprezentowało interesy biedniejszych warstw społeczeństwa, a przede wszystkim średniozamożne chłopstwo, rzemieślników oraz drobnych fabrykantów i, jak wspominał Grzegorzewski,: „, mieli się za nieodrodnych synów ludu, wygłodzonego pięciowiekową niewolą"11. Natomiast drugi obóz, tzw. starzy pod przywództwem Todora Ikomonowa, wspieranego przez Dimityra Grekowa, Konstantina Stoiłowa i Grigora Naczowicza, występował w imieniu bogatego chłopstwa, kupców i przemysłowców bułgarskich ${ }^{12}$. Oba te nurty wkrótce przekształciły się w dwie pierwsze partie polityczne w Bułgariii ${ }^{13}$.

Przeciągające się spory w kwestii konstytucji pasywnie obserwowali zarówno przedstawiciele tymczasowej administracji rosyjskiej, jak i rząd w Petersburgu. Postawa taka wynikała zdaniem Grzegorzewskiego stąd, że jakkolwiek część kręgów politycznych w Rosji kwestionowała, a nawet kontestowała liberalne zapisy, które znalazły się w projekcie bułgarskiej ustawy zasadniczej, to gabinet carski nie przywiązywał do nich szczególnej uwagi „skoro nieunikniony w następstwie tej konstytucji konflikt chroniczny między panującym a rządem, tudzież między każdym z tych czynników państwowych a ludnością, dawał dostateczną możliwość interwencyi rządu rosyjskiego i nadzieję utrwalenia w ten sposób wpływu jego w Bułgaryi" ${ }^{14}$. Stąd też większą aktywność Rosjanie wykazywali tylko w kwestii wyboru monarchy, starając się skupić zwaśnione strony wokół osoby wskazanego

9 Ibidem.

10 J. Grzegorzewski, Rok przewrotów..., s. 34.

11 J. Grzegorzewski, Stronnictwa bułgarskie za Aleksandra Battenberga..., s. 82-83; Програми, програмни документи и устави на буржоазните партии в България 1879-1918, съст. В. Николова, Д. Саздов, София 1992, s. 17.

12 J. Grzegorzewski, Stronnictwa bułgarskie za Aleksandra Battenberga..., s. 82; Програми, програмни документи..., s. 44.

13 Odnosząc się do sporów toczonych przez przedstawicieli obu nurtów w czasie posiedzeń Konstytuanty, Grzegorzewski wskazuje jeszcze jedno środowisko skupione wokół Marko Bałabanowa i wspierane przez wyższe duchowieństwo z byłym egzarchą bułgarskim Antymem I na czele, określane mianem centrum, które starało się godzić zwaśnione strony. Działania te nie zakończyły się jednak powodzeniem, a po zakończeniu obrad grupa rozpadła się, nie tworząc żadnego ugrupowania. Bałabanow wszedł później w skład Partii Konserwatywnej, stworzonej przez konserwatystów, J. Grzegorzewski, Stronnictwa bułgarskie za Aleksandra Battenberga..., s. 83.

14 Ibidem, s. 84. 
w Petersburgu kandydata - Aleksandra Battenberga ${ }^{15}$, a ponieważ jego osoba nie budziła kontrowersji, został on powołany na tron bułgarski ${ }^{16}$.

Obejmujący rządy w Bułgarii Aleksander stanął przed poważnymi wyzwaniami, które były pochodną trudnej sytuacji społeczno-ekonomicznej państwa. Z punktu widzenia bułgarskiej racji stanu najistotniejszą kwestią było jak najszybsze uregulowanie kwestii przejmowania opuszczonych przez Turków majątków, zaopatrzenie chłopów w ziemię i wyeliminowanie coraz częstszych przypadków spekulacji w rolnictwie, które groziły wybuchem poważnych niepokojów społecznych. Tymczasem spory między konserwatystami a liberałami zaostrzały się, co ograniczało możliwość podjęcia zdecydowanych kroków w tych palących kwestiach, a na skutek oporu „młodych”"17 fiaskiem zakończyły się próby powołania koalicyjnego gabinetu. Stąd też Aleksander podjął decyzję o powierzeniu misji formowania pierwszego bułgarskiego rządu konserwatystom ${ }^{18} \mathrm{i}$ jednocześnie rozpisał wybory parlamentarne. Te jednak wbrew oczekiwaniom przyniosły pełne zwycięstwo liberałom, o czym zadecydowała przede wszystkim bierna postawa „starych” w trakcie kampanii wyborczej ${ }^{19}$. Nie zakończyło to jednak wewnętrznych sporów, co skłoniło sterowanego przez Rosję księcia do rozwiązania Zgromadzenia Narodowego i utworzenia nowego gabinetu pod kierownictwem biskupa Klimenta. Jakkolwiek rząd ten miał koalicyjny charakter, główną rolę odgrywali w nim konserwatyści, co nie tylko nie wyciszyło sporów, ale jeszcze zaostrzyło rywalizację między obiema grupami. W tej sytuacji Aleksander Battenberg pod koniec 1879 r. po raz kolejny rozwiązał parlament, licząc że kolejne wybory pozwolą konserwatystom zdobyć większość, stanowiącą oparcie dla gabinetu. Jednak przeprowadzone na przełomie stycznia i lutego następnego roku wybory znowu zakończyły się spektakularnym sukcesem liberałów. Jednocześnie sytuacja wewnętrzna w Bułgarii uległa dalszemu pogorszeniu na skutek licznych buntów chłopskich i poważnych błędów popełnionych przez rząd Klimenta.

15 Zabiegi na tym polu były jednak niepotrzebne, ponieważ, jak pisał Grzegorzewski: „Masy bułgarskie wraz z całą inteligencyą z takiem były wówczas ślepem oddaniem Rosyi, że gdyby kazano wybrać pałkę pod koronę, wybranoby bez protestu", ibidem.

16 Ibidem, s. 84, 91; C. Jireček, Geschichte der Bulgaren, Prag 1876, s. 323; A. Pług [A. Pietkiewicz], Sprawa Bułgarska, „Kłosy” 41 (1885), nr 1059, s. 246-247; Д. Маринов, Стефбан Стамболов и новейшата ни история, т. 1, София 1992, s. 81-100.

17 J. Grzegorzewski, Stronnictwa bułgarskie za Aleksandra Battenberga..., s. 86.

18 Premierem tego rządu został Todor Burmow. Ibidem; Външната политика на България. Документи и материали, ред. Д. Косев, т. 1, София 1978, s. 17; C. Jireček, op. cit., s. 322, 325; Н. Станев, История на нова България 1878-1928, София 1929, s. 18; А. Цураков, Правителствата на България, ч. 1, София 1996, s. 7-11.

19 Jak pisał Grzegorzewski: „Nieco ociężali konserwatyści bądź zostawiali wolny bieg wyborom, bądź nic nie przedsiębrali przeciw szalonej agitacyi przeciwników w prasie, na zgromadzeniach ludowych, w tworzonych ad hoc stowarzyszenich, wreszcie osobistymi zabiegami agentów wyborczych, popieranych przez własnych urzędników rządu”, idem, Stronnictwa bułgarskie za Aleksandra Battenberga..., s. 88. 
Trwające w Bułgarii spory polityczne, a także wyniki wyborów $\mathrm{z}$ uwagą obserwowane były w Petersburgu. Ten stan rzeczy wynikał przede wszystkim z faktu, że rywalizujące do tej pory głównie w kwestiach wewnętrznych bułgarskie stronnictwa zaczęły w tym czasie kreować swoje poglądy w kwestiach polityki zagranicznej. Popierani przez Battenberga i reprezentujący bogatsze grupy społeczeństwa konserwatyści coraz częściej opowiadali się za zacieśnieniem stosunków z mocarstwami zachodnimi, co ich zdaniem stworzyłoby szanse szybszego rozwoju gospodarki bułgarskiej niż współpraca ze słabą ekonomicznie Rosją. Realna możliwość utraty kontroli nad Bułgarią skłoniła władze carskie do zwrócenia większej uwagi na „młodych”, którzy jakkolwiek często szermowali w dyskusjach hasłami rewolucyjnymi, manifestowali jednocześnie swoje pozytywne nastawienie do Rosji. Stąd też na skutek zabiegów dyplomatów rosyjskich, Aleksander zmuszony był powołać kolejny gabinet, tym razem liberalny, pod kierownictwem Cankowa.

Trzynastomiesięczne rządy dwóch następujących po sobie rządów „młodych” Jan Grzegorzewski oceniał negatywnie. Szczególne słowa krytyki kierował on pod adresem obu premierów - Cankowa i Karawełowa, zarzucając im nie tylko brak doświadczenia i wyczucia politycznego ${ }^{20}$, ale także ogłady, a nawet elementarnych zasad wychowania. O drugim z nich Grzegorzewski pisał:

Karawełow, któremu Dawidow, poprzedni agent rosyjski, wzdragał się podać rękę pod pozorem, że się nie umywa, zjawiał się bez ceremoniału w gabinecie księcia w żakiecie negliżowym, z rozczochranymi włosami głowy i brody, a gestykulując namiętnie rękoma, lub w gwałtownych ruchach rzucając się z konta w kąt [sic!], wywoływał w obronie swych referatów i planów tak namiętne dyskusye, że książę uciekał do dalszych apartamentów i pozostawiał go samego ${ }^{21}$.

Grzegorzewski krytycznie wyrażał się także o wyraźnie prorosyjskim kursie reprezentowanym przez liberałów, uznając go za wręcz szkodliwy dla Bułgarii, oraz o ich wysiłkach na rzecz ograniczenia kompetencji monarchy. Warto jednak pamiętać, że poza wskazanymi i docenionymi przez Grzegorzewskiego zmianami w systemie fiskalnym, „młodzi” przeprowadzili także doniosłe reformy w sferze administracyjnej i agrarnej, co w znaczący sposób wpłynęło na stabilizację sytuacji w kraju. Narastały też nieporozumienia na linii rząd - monarcha, co motywowało Aleksandra do podejmowania działań na rzecz odsunięcia liberałów od władzy.

Do ostatecznego starcia doszło w 1881 r. Wykorzystując objęcie władzy w Rosji przez nowego cara Aleksandra III, po uzyskaniu jego akceptacji Battenberg zawiesił konstytucję i odwołał rząd liberałów, a misji sformowania nowego gabinetu podjął się przybyły z Petersburga gen. Johan Casimir Ehrnrooth. Jednocześnie rozpisano wybory do Wielkiego Zgromadzenia Narodowego, które miało usankcjonować istniejący stan rzeczy i zaaprobować przedstawiony przez Battenberga

${ }^{20}$ J. Grzegorzewski, Stronnictwa bułgarskie za Aleksandra Battenberga..., s. 93-94.

${ }^{21}$ Ibidem, s. 91. 
projekt zmian ${ }^{22}$. Dzięki wprowadzeniu stanu wyjątkowego w kraju oraz podjętym działaniom prewencyjnym większość w parlamencie zdobyli konserwatyści, którzy bez dyskusji przyznali księciu pełnomocnictwa „wśród owacyi miejscowej i przybyłej z prowincyi ludności"23. Następnie Zgromadzenie zostało rozwiązane, a do dymisji podał się gabinet Ehrnrootha, który wkrótce zastąpiła pełniąca rolę rządu i parlamentu ${ }^{24}$ Rada Państwa. Jednocześnie podjęto działania na rzecz usunięcia liberałów z bułgarskiej sceny politycznej, rugując z rynku prasowego wspierające ich gazety i czasopisma oraz aresztując lub zmuszając do emigracji część ich liderów i działaczy ${ }^{25}$.

Jakkolwiek przyniosło to poprawę sytuacji wewnętrznej w kraju, brutalne działania przeciw prorosyjsko nastawionym „młodym” zaczęły budzić zaniepokojenie w Petersburgu. Na negatywną ocenę Aleksandra Battenberga wpływał także otwarty konflikt między nim, a posłem rosyjskim w Sofii Michaiłem Chitrowo, który wybuchł na tle sporu o przyznanie koncesji na budowę nowych połączeń kolejowych w Bułgariii ${ }^{26}$. Dlatego też informowany na bieżąco o nastrojach w Rosji Battenberg zwrócił się do cara Aleksandra III z prośbą o wydelegowanie dwóch osób do objęcia stanowisk rządowych, a w skład nowego gabinetu weszli gen. Leonid Sobolew jako premier oraz gen. Aleksander Kaułbars jako minister wojny. Wbrew nadziejom zabieg ten nie wzmocnił jednak pozycji księcia, a przyczyną takiego stanu rzeczy były przede wszystkim zakulisowe działania prezesa Rady Ministrów, który wysyłał do Petersburga raporty „przedstawiające konserwatystów jako zgraję oszustów, księcia - jako przedanego Austryi, wyrywającego Bułgaryę z rąk rosyjskich a poddającego ją Niemcom" 27 . Nasilający się spór w łonie rządu szybko przerodził się w kryzys gabinetowy. Na początku marca 1883 r. „starzy” opuścili gabinet, co zmusiło Battenberga do zainicjowania rozmów pomiędzy popierającymi

22 Przewidywał on zawieszenie konstytucji na siedem lat. W tym czasie pełna władza ustawodawcza i wykonawcza miała znajdować się w rękach Aleksandra. Książę uzyskał także nadzwyczajne pełnomocnictwa, które zapewnić mu miały możliwość dokonania zmian w ustawie zasadniczej, ibidem, s. 95.

${ }^{23}$ Ibidem, s. 100.

${ }^{24}$ Jak pisał Grzegorzewski: „W zakresie działania tej Rady leżało rozstrzyganie skarg przeciw wyższym władzom administracyjnym, składanie księciu opinii o naruszeniu konstytucji, tudzież ministerstwu na jego kwestyonaryusze, udzielanie nadzwyczajnych kredytów, przygotowywanie projektów do ustaw itd.", ibidem.

25 J. Grzegorzewski, Dragan Cankow..., s. 358; idem, Stronnictwa bułgarskie za Aleksandra Battenberga..., s. 102.

26 J. Grzegorzewski, Stronnictwa bułgarskie za Aleksandra Battenberga..., s. 87, 90, 101. Na ten temat także: C. Jireček, op. cit., s. 329; Н. Станев, ор. cit., s. 32-33; А. Цураков, op. cit., s. 21; Е. Стателова, Дипломация на Княжество България 1879-1886, София 1979, s. 81-90. Konflikt na tym tle rozpoczął się już w 1880 r. w związku z zabiegami o koncesję na budowę linii Ruse - Sofia, podjętymi przez rosyjskiego przemysłowca Aleksandra Ginburga. Wspierana przez rosyjską dyplomację i liberałów idea natrafiła jednak na opór Battenberga i konserwatystów, którzy opowiadali się za przyznaniem koncesji spółkom zachodnioeuropejskim.

${ }^{27}$ J. Grzegorzewski, Stronnictwa bułgarskie za Aleksandra Battenberga..., s. 104. 
go konserwatystami a liberałami na temat porozumienia. Latem tego roku zakończyły się one sukcesem ${ }^{28}$, co nie tylko umożliwiło rozpisanie wyborów do Zgromadzenia Narodowego, w którym zdecydowaną większość posiadali konserwatyści, ale zapoczątkowało rozpad obozu liberalnego ${ }^{29}$. Podczas inauguracyjnej sesji parlamentu 6 września Battenberg ogłosił manifest, w którym zapowiedział przywrócenie konstytucji oraz wydał dekret o powołaniu nowego koalicyjnego rządu, na czele którego stanął liberał Dragan Cankow jako premier oraz konserwatysta Grigor Naczowicz jako minister finansów ${ }^{30}$. W tej sytuacji generałowie rosyjscy opuścili Bułgarię, „zostawiając groźbę księciu na pożegnanie: «Nous nous retirons, mais souvenez vous que pour vous même cette affaire sera funeste»" ${ }^{31}$.

Zawarte między konserwatystami a liberałami porozumienie nie przetrwało jednak długo. Do sporów dochodziło zarówno na posiedzeniach gabinetu, jak i w Zgromadzeniu Narodowym, a ostatecznie kontrowersje, które zaistniały w kwestii powołania wyższej izby parlamentu i zmian w ordynacji wyborczej pod koniec 1883 r. przesądziły o upadku rządu. Jego miejsce zajął nowy gabinet złożony z liberałów pod kierownictwem Cankowa. Nie uspokoiło to jednak sytuacji, ponieważ do zmasowanego ataku przystąpiła pozostająca w opozycji frakcja liberałów skupiona wokół Petko Karawełowa, zawiedziona w nadziejach na uzyskanie stanowisk rządowych. W licznych publikacjach zarzucała ona Cankowowi „zdradę liberalizmu i niemal zdradę interesów kraju za podpisanie konwencyi o budowę kolei SofiaBelgrad (na Carybrod-Nisz, nie zaś na Skopię macedońską)"32, a także wytykano mu zbyt ugodową postawę w sporze granicznym z Serbią i nadużycia przy zakupie przez państwo linii kolejowej Ruse-Warna. Taki stan rzeczy spowodował kolejny kryzys polityczny, którego efektem była z jednej strony dymisja rządu i rozwiązanie parlamentu, a z drugiej - ostateczny rozpad obozu liberalnego na dwa antagonistycznie do siebie nastawione stronnictwa ${ }^{33}$. Jednocześnie $\mathrm{w}$ przeprowadzonych

${ }^{28}$ Ibidem, s. 108.

${ }^{29} \mathrm{~W}$ rozmowach z konserwatystami zdecydowało się wziąć udział tylko umiarkowane skrzydło liberałów, skupione wokół Cankowa. Pozostali, pod przywództwem przebywającego na emigracji w Rumelii Wschodniej Karałewowa, nadal pozostali w opozycji.

${ }^{30}$ J. Grzegorzewski, Stronnictwa bułgarskie za Aleksandra Battenberga..., s. 112.

31 (fr.) „Wyjeżdżamy, ale pamiętajcie, że będzie to miało dla was fatalne skutki”, ibidem, s. 108.

32 Ibidem, s. 113. Decyzję w tej kwestii podjął jeszcze koalicyjny gabinet liberałów i konserwatystów, a szczególnej krytyce poddano przyznanie koncesji na budowę kompanii austro-węgierskiej.

${ }^{33} \mathrm{~W}$ związku z tym, że oba odwoływały się do tradycji liberalnej, dla rozróżnienia - zwolenników Cankowa zaczęto nazywać „cankowistami”, a grupę Karawełowa „karawelistami”. Warto także zaznaczyć, że zdaniem Grzegorzewskiego głównym powodem tego rozpadu były przede wszystkim względy ambicjonalne i rywalizacja między liderami, a nie głębsze różnice ideologiczne. Obrazowo zaprezentował to pisząc: „Przeciwieństwa zaostrzyły się osobistym stosunkiem między przywódcami do tyla, że jak Cankow odezwał się - w niebie gdyby spotkał Karawełowa, uciekłby stamtąd do piekła”, idem, Stronnictwa bułgarskie za Aleksandra Battenberga..., s. 114; idem, Dragan Cankow..., s. 358. Jednocześnie jednak zmieniały się poglądy obu liderów na kierunki bułgarskiej polityki zagranicznej. O ile Cankow prezentował zdecydowanie prorosyjskie nastawienie, Karawełow zaczął skłaniać się ku mocarstwom zachodnim. 
w maju 1884 r. wyborach do kolejnego Zgromadzenia Narodowego zwycięstwo odniosła grupa $z$ Karawełowem na czele, on sam objął rządy jako premier rządu, a Cankow ze swoją grupą znalazł się w opozycji. Tym samym sytuacja w kraju nadal była napięta, co skłaniało różne czynniki do podjęcia działań na rzecz zbliżenia między oboma stronnictwami. Jak pisał Grzegorzewski: „By wszakże tymczasem na ziemi bułgarskiej pojednali się i działali zgodnie - pragnęli tego bardzo książę Aleksander, jak i nowy agent dyplomatyczny Rosyi - Kojander, choć w kierunku i celach sprzecznych" ${ }^{34}$.

Wysiłki dyplomacji rosyjskiej podyktowane były przede wszystkim snutymi już od jakiegoś czasu w Petersburgu planami usunięcia Aleksandra $\mathrm{z}$ tronu bułgarskiego. Ponieważ zdawano sobie sprawę z faktu, że bezpośrednia ingerencja Rosji może spotkać się z reakcją innych mocarstw europejskich, zdecydowano się wpierać tę część bułgarskiej sceny politycznej, która kontestowała jego rządy w Bułgarii. W zaistniałej sytuacji konieczne stało się jednak skłonienie obu ugrupowań liberalnych do współpracy. Działania w tej kwestii, jak pisze Grzegorzewski powołując się na pracę Simeona Radewa ${ }^{35}$, Kojander rozpoczął wkrótce po przybyciu do Sofii wiosną 1884 r., a podczas zaaranżowanego spotkania obu liderów zakomunikował im: „Stosunki z Rosyą są bardzo naprężone - jak wam wiadomo. Książę Aleksander musi albo pogodzić się z cesarzem, albo opuścić Bułgaryę. Jeśli wam się zdaje, że pogodzenie się jest pożądane, gotów jestem w tym celu natychmiast wyjechać do Petersburga, jeśli zaś nie, to kwestia detronizacyi musi się rozstrzygnąć jak najrychlej"36. Jakkolwiek idea usunięcia Battenberga przypadła do gustu obu liderom, Cankow, obawiając się ewentualnych następstw, proponował stworzenie z konserwatystami koalicyjnego rządu, który solidarnie wziąłby na siebie odpowiedzialność za złożenie monarchy z tronu. Idea współpracy z konserwatystami została jednak odrzucona przez Karawełowa i mimo że podpisano porozumienie o współpracy, działania w tym obszarze nie zostały podjęte ${ }^{37}$. Jednocześnie o porozumienie między liderami liberałów starał się także Battenberg, który w takim aliansie widział narzędzie do przeciwdziałania obcej, w tym także rosyjskiej penetracji w Bułgarii ${ }^{38}$, ale te zabiegi również nie zakończyły się powodzeniem. Nie ulega wątpliwości, że na taki stan rzeczy bezpośredni wpływ miała ówczesna sytuacja polityczna w Europie, która stawiała Bułgarów w trudnej sytuacji. Jak słusznie zauważył Grzegorzewski:

Gdyby zachowanie ich wobec Rosyi i Zachodu abstrahować od wszelkich sentymentów i czynników historyczno-kulturalnych, a oceniać je tylko na gruncie istniejącej konkretnej

${ }^{34}$ J. Grzegorzewski, Stronnictwa bułgarskie za Aleksandra Battenberga..., s. 114.

35 С. Радев, op. cit., т. 1, s. 458.

36 J. Grzegorzewski, Stronnictwa bułgarskie za Aleksandra Battenberga..., s. 115.

37 Odnosząc się do zaczerpniętych od Radewa informacji, Grzegorzewski, nie odmawiając im prawdziwości, powątpiewa, aby działania takie były możliwe do zrealizowania, ibidem, s. 116.

38 Ibidem, s. 117-118. 
polityki ówczesnej, to ludzie tacy jak Karawełow i Cankow, co to będąc ministrami już się zetknęli z wielką kuźnicą tej polityki, łudzić się nie mogli myślą, że Europa wypowie wojnę Rosyi w obronie wolności bułgarskiej, a tem mniej jej księcia ${ }^{39}$.

Zdając sobie z tego sprawę, politycy bułgarscy starali się nie podejmować działań, które mogłyby wpływać na negatywną ocenę Bułgarii na arenie międzynarodowej. Była to postawa tym bardziej pożądana, że w decydującą fazę wchodziła wówczas kwestia przyszłości utworzonej na mocy traktatu berlińskiego autonomicznej prowincji tureckiej Rumelii Wschodniej. Ta zamieszkana w znakomitej większości przez ludność bułgarską prowincja pozostawała pod bezpośrednią polityczną i wojskową kontrolą Turcji, ale - zgodnie z wolą mocarstw - wyposażona została w chrześcijańskiego gubernatora, lokalny rząd, stanowiące namiastkę parlamentu Zgromadzenie Prowincjonalne oraz prowincjonalną milicję ${ }^{40}$.

Pierwszym generalnym gubernatorem Rumelii Wschodniej został Bułgar z pochodzenia, Aleko Pasza Bogoridi, który „zrzuciwszy fez turecki a przywdziawszy kołpak narodowy, w porozumieniu z pierwszym konsulem rosyjskim Ceretelewem [Aleksiej Cereteli], Gruzinem, i tegoż sekretarzem Izwolskim, przeprowadził nominacye samych Bułgarów na stanowiska tak dyrektorów rządu (godność odpowiadająca ministrom księstwa północnego), jak i prefektów departamentów" ${ }^{41}$. Jednocześnie w Rumelii zaczęły kształtować się - podobnie jak w Księstwie Bułgarii - dwa nurty polityczne. $\mathrm{Na}$ ich czele stanęli Iwan Sałabaszew i Iwan Ewstratiew Geszow, ale początkowo nie przejawiały one większej aktywności ${ }^{42}$. Sytuacja zmieniła się dopiero w 1881 r., kiedy do Rumelii przybyli zagrożeni aresztowaniem w Księstwie Karawełow i Sławejkow ${ }^{43}$, którzy w założonym przez siebie w Płowdiwie czasopiśmie „Niezawisimost” rozpoczęli ożywioną kampanię skierowaną przeciw Aleksandrowi Battenbergowi. Jednocześnie włączyli się w trwającą dyskusję na temat ewentualnego zjednoczenia Rumelii Wschodniej z Księstwem Bułgarii, wspierając ideę unii. Na tym gruncie doszło do zbliżenia między nimi a popieraną przez gubernatora Bogoridiego grupą Sałabaszewa, która określiła się mianem liberałów. Jednak mimo wygranych przez ugrupowanie liberalne w 1883 r. wyborów do Zgromadzenia Prowincjonalnego, lansowana przez nie idea szybkiego zjednoczenia Bułgarii nie weszła w fazę realizacji na skutek zmian, które zaszły w Rumelii.

Rok później gubernatorem generalnym wybrany został Gawrił Pasza Krestowicz, który rozwiązał Zgromadzenie i rozpisał nowe wybory, umożliwiając przejęcie

39 Ibidem, s. 120.

40 J. Grzegorzewski, Rok przewrotów..., s. 3; H. von Bilimek-Waissolm, Der bulgarisch-serbisch Krieg 1885, Wien 1886, s. 2; J. Rubacha, A. Malinowski, Historia Bułgarii 1870-1915. Materiały źródłowe z komentarzami, t. 3: Polityka wewnętrzna, Warszawa 2009, s. 43-50.

41 J. Grzegorzewski, Stronnictwa bułgarskie za Aleksandra Battenberga..., s. 128.

42 J. Grzegorzewski, Rok przewrotów..., s. 4-5, 113.

43 Ibidem, s. 51. 
władzy przez konserwatystów skupionych wokół Geszowa ${ }^{44}$. Grupa ta, pod naciskiem dyplomacji rosyjskiej, stanęła na stanowisku, że zjednoczenie powinno odbyć się na drodze ewolucyjnego procesu i opowiedziała się za odłożeniem go na bardziej sprzyjający moment ${ }^{45}$. Pozbawieni wpływu na bieg wypadków liberałowie zdecydowali się rozpocząć działania zakulisowe. $Z$ ich inicjatywy założono w Płowdiwie konspiracyjny Bułgarski Tajny Centralny Komitet Rewolucyjny (BTCKR) z Zachari Stojanowem ${ }^{46}$ na czele, który rozpoczął ożywioną akcję propagandową wśród mieszkańców prowincji, cieszącą się dużą popularnością ${ }^{47}$. Komitet nawiązał także kontakty z Aleksandrem Battenbergiem ${ }^{48}$, a w trakcie przeprowadzonych w połowie sierpnia 1885 r. rozmów wyznaczono termin podjęcia akcji na koniec następnego miesiąca. Tymczasem sytuacja w Rumelii uległa zaognieniu, a w wielu miejscowościach dochodziło do wystąpień ludności. Miejscowa milicja, której dowódcy uczestniczyli w działalności spiskowej, najczęściej nie reagowała. Taki stan rzeczy skłonił w połowie września władze do podjęcia decyzji o aresztowaniu kilku oficerów i Stojanowa ${ }^{49}$. Na wieść o tym BTCKR postanowił przyspieszyć działania. Jak pisał Grzegorzewski, nad ranem 18 września

500 chłopów zbrojnych z Czardafonem Welikim [Prodan Prodanow] i jego narzeczoną Nadelką, z rozwiniętemi chorągwiami i okrzykami na cześć zjednoczenia łączą się na ulicach Płowdiwa z milicyą Nikołajewa, który ich prowadzi do pałacu wielkorządcy. Po mowie ekscytującej kapitana Fiłowa, okrzykach hurra i dźwiękach dzwonów cerkwi, Stojanow aklamuje koniec rządów wielkorządcy tureckiego. Wyprowadzono Krestowicza pod operetkową strażą Nadelki, posadzonej z pałaszem obok niego w powozie, odwożą ku granicy i puszczają na wolność. To samo dzieje się z jenerałem Drygalskim, komendantem sił zbrojnych dotychczasowej autonomicznej prowincyi Turcji, a odtąd zjednoczonej z księstwem. Zjednoczenie faktem dokonanym ${ }^{50}$.

${ }^{44}$ Ibidem, s. 6.

45 J. Grzegorzewski, Stronnictwa bułgarskie za Aleksandra Battenberga..., s. 131.

46 J. Grzegorzewski, Rok przewrotów..., s. 8. Charakteryzując jego postać Grzegorzewski nie szczędził krytycznych słów, ale nie krył także swego podziwu: „W zastępie owych nowych prowodyrów idei na pierwsze stanowisko wyforowuje się Zachari Stojanow, jeden z tych talentów z Bożej łaski, które jak meteor spadają nagle na ziemię w noc ciemną , rozświetlają horyzont ludziom i nikną, pozostawiając im żużle spalone aerolitu - zamiast oglądanej dotychczas gwiazdy. Z zawodu kolejno pastuch i kałfa (czeladnik) krawiecki, zostaje dziennikarzem, sędzią śledczym, organizatorem spisku i przewrotu, wreszcie już po unii posłem i marszałkiem sejmowym, bez i protekcyi”, idem, Stronnictwa bułgarskie za Aleksandra Battenberga..., s. 131, 137; na ten temat także: idem, Rok przewrotów..., s. 7-8.

47 J. Grzegorzewski, Stronnictwa bułgarskie za Aleksandra Battenberga..., s. 137-138.

48 J. Grzegorzewski, Rok przewrotów..., s. 11-14; idem, Stronnictwa bułgarskie za Aleksandra Battenberga..., s. 131.

49 J. Grzegorzewski, Stronnictwa bułgarskie za Aleksandra Battenberga..., s. 138; idem, Rok przewrotów..., s. 14-16; R. von Mach, Elf Jahre Balkan. Erinnerungen eines preussischen Offiziers aus den Jahren 1876-1887, [Breslau] 1889, s. 245.

50 J. Grzegorzewski, Stronnictwa bułgarskie za Aleksandra Battenberga..., s. 138-139. W innym miejscu (idem, Rok przewrotów..., s. 17), liczbę insurgentów Grzegorzewski szacował na 700 osób. 
Władzę w prowincji przejął Komitet Tymczasowy z Gieorgi Stranskim na czele $^{51}$, który natychmiast zwrócił się do Księstwa Bułgarii z prośbą o pomoc ${ }^{52}$, a do cara rosyjskiego $\mathrm{z}$ prośbą o otoczenie unii opieką. $\mathrm{W}$ tym czasie, informowany o rozgrywających się w Rumelii Wschodniej wydarzeniach, Aleksander Battenberg ogłosił powszechną mobilizację bułgarskich sił zbrojnych ${ }^{53}$ i wyruszył do Płowdiwu. 20 września w Wielkim Tyrnowie ogłosił manifest, w którym proklamował zjednoczenie i ogłosił się księciem Północnej i Południowej Bułgarii ${ }^{54}$, a następnego dnia przybył do rumelijskiej stolicy.

Nie ulega wątpliwości, że proklamowanie zjednoczenia wywołało wśród Bułgarów powszechną radość 55 , ale jednocześnie spotkało się z negatywnym przyjęciem w Europie. Szczególnie mocno zaprotestowały przeciw unii bułgarskiej inne państwa bałkańskie, a zwłaszcza Turcja ${ }^{56}$, Serbia i Grecja, które postrzegały ją jako zagrożenie własnych interesów ${ }^{57}$. Krytycznie odniosły do niej także Rosja, nieżycząca sobie żadnych zmian w staus quo na Bałkanach, oraz popierające Serbię Austro-Węgry. Zgodna negatywna ocena zjednoczenia Księstwa Bułgarii i Rumelii Wschodniej dokonana przez oba rywalizujące na Półwyspie Bałkańskim mocarstwa skłoniła króla serbskiego Milana do zbrojnego wystąpienia przeciw Bułgarii 14 listopada $1885 \mathrm{r}$.

Konflikt z Serbią postawił Bułgarię w bardzo trudnym położeniu. W odpowiedzi na unię bułgarską Turcja dokonała koncentracji swojej armii na granicy rumelijskiej i jakkolwiek nie zdecydowała się interweniować, zagrożenie ze strony południowego sąsiada było poważne, co zmuszało Bułgarów do utrzymywania w Rumelii znacznej części ich sił, z dala od północnego teatru wojennego. Wielkie mocarstwa, mimo że zabiegały o wzmocnienie swych wpływów w Księstwie Bułgarii, nie zamierzały interweniować $w$ jego obronie. Wręcz przeciwnie. Austro-Węgry udzieliły Serbii pożyczki na cele wojenne, a Rosja odwołała swoich oficerów, zajmujących się dotąd szkoleniem młodej armii bułgarskiej ${ }^{58}$, co mogło poważnie ograniczyć jej możliwości. Jak jednak zauważył Grzegorzewski, Bułgarzy górowali nad Serbami swym - jak to określił - „temperamentem narodowym”, który charakteryzował następująco:

${ }^{51}$ J. Grzegorzewski, Rok przewrotów..., s. 19, 50, 112; C. Jireček, op. cit., s. 349; E. Lipnicki, Sprawa bułgarska, „Biblioteka Warszawska” 1886, t. 1, s. 183; Е. Стателова, Р. Попов, В. Танкова, История на българската дипломация 1879-1913 г., София 1994, s. 46.

52 J. Grzegorzewski, Rok przewrotów..., s. 19; Сръбско-българската война 1885. Сборник документи, съст. Е. Харбова, Л. Цветкова, С. Шанов, София 1985, s. 18; Външната политика..., т. 1, s. 562; na ten temat także: A. Pług, op. cit., s. 246.

53 J. Grzegorzewski, Rok przewrotów..., s. 26.

54 Tekst manifestu: J. Grzegorzewski, Rok przewrotów..., przyp. ${ }^{\star *}$, s. 21; J. Rubacha, A. Malinowski, op. cit., s. 76-77.

55 J. Grzegorzewski, Rok przewrotów..., s. 20, 25-26; R. von Mach, op. cit., s. 248-252, 259.

56 J. Grzegorzewski, Rok przewrotów..., s. 90-94.

57 Ibidem, s. 60; C. Jireček, op. cit., s. 350.

58 J. Grzegorzewski, Rok przewrotów..., s. 38, 84. 
Bułgar jest ostrożnym i spokojnym ale stanowczym i wytrwałym; nie łatwo zraża się on klęską, może dziesięć bitew przegrać i do jedenastej pójść z całym spokojem; pod tym względem po tureckim żołnierzu przedstawia najznakomitszy materyał dla wojska. Serb, przeciwnie, ma więcej fantazyi, zapału i entuzjazmu, ale obok tego jest wrażliwym; pójdzie on z większą brawurą w ogień, ale dłuższego oporu nie wytrzyma, zwycięstwo zachęci go do cudów waleczności, ale pierwsza większa przegrana może być stanowczą klęską dla niego. W ogóle mówiąc, Serbia bardziej mogła wygrać kampanię dzięki oficerom, Bułgarya - dzięki żołnierzom ${ }^{59}$.

Przewidywania te w pełni potwierdziły się na placu boju.

Początkowo jednak dysponująca przewagą liczebną armia serbska przejęła inicjatywę i nie tylko odrzuciła bułgarskie oddziały pograniczne, ale przerwała linie obronne pod Tryn, Caribrodem i Kułą, a sytuacja Bułgarów, zarówno pod względem taktycznym, jak i strategicznym stała się bardzo poważna. Czekając na posiłki z południa ${ }^{60}$, przybyły z Płowdiwu Aleksander Battenberg zdecydował się ulokować ostatni punkt obrony w okolicach miejscowości Sliwnica, położonej ok. $40 \mathrm{~km}$ od Sofii. Jakkolwiek była to bardzo ryzykowna decyzja, 16 listopada rozpoczęto intensywne prace fortyfikacyjne. Już następnego dnia na tych pozycjach rozpoczęła się mająca trwać trzy dni, główna bitwa całej wojny ${ }^{61}$. W dniu 17 listopada nacierające na tym kierunku serbskie siły główne pod osobistym dowództwem króla Milana zaatakowały bułgarskie linie obronne, ale mimo znacznej przewagi liczebnej nie udało im się ich przełamać. Dodatkowo Bułgarzy wykonali kontratak, w wyniku którego opanowali wyżynę Meka Crew i zmusili jednostki lewego skrzydła serbskiego do wycofania. Mimo to Serbowie zaatakowali ponownie następnego dnia, ale i tym razem zostali odparci i ponieśli ciężkie straty ${ }^{62}$. W tym momencie na placu boju pojawiły się posiłki $\mathrm{z}$ Rumeliii ${ }^{63}$, co pozwoliło bułgarskiemu dowództwu przedsięwziąć kontratak, w wyniku którego udało się pobić serbskie oddziały pod Komszticą i zagrozić bezpośrednio stacjonującemu w Caribrodzie serbskiemu Sztabowi Generalnemu. Przerażony król Milan wycofał się do Pirotu ${ }^{64}$. Sukcesy odnieśli Bułgarzy także na innych odcinkach frontu. Następnego dnia udało im się rozbić podążającą od strony Trynu dywizję serbską i wyprowadzić uderzenie spod Sliwnicy w kierunku Caribriodu, który po ciężkich walkach zajęli 23 listopada.

59 Ibidem, s. 68; na ten temat także: E. Lipnicki, Sprawa bułgarska..., s. 377.

${ }^{60}$ Kwestię szybkiej zmiany dyslokacji jednostek traktowano priorytetowo. Jak wspominał przebywający wówczas w Płowdiwie Grzegorzewski: „część wiozły nieustanne pociągi kolejowe, reszta, nienadająca się w nich zmieścić, ciągnęła zwykłymi gościńcami. Filipopol w ciągu trzech dni przedstawiał obraz ruchomego obozu zbrojnego, wsiąkającego w siebie coraz to nowe kolumny piechoty, kawaleryi i artyleryi i następnie wyrzucającego je bez końca w przestwór bałkański”, J. Grzegorzewski, Rok przewrotów..., s. 67.

${ }^{61}$ Opis bitwy wg relacji Antoniego Piotrowskiego: ibidem, s. 74-80.

62 Сръбско-българската война..., s. 304-305.

${ }^{63}$ R. von Mach, op. cit., s. 277-282.

${ }^{64}$ E. Lipnicki, Sprawa bułgarska..., s. 377. 
Trzy dni później wojska bułgarskie przekroczyły serbską granicę i zajęły Pirot. Dalsze postępy armii bułgarskiej zostały jednak powstrzymane na skutek interwencji posła austro-węgierskiego w Belgradzie, hr. Rudolfa Khevenhüllera, który 28 listopada 1885 r. zażądał natychmiastowego wstrzymania ofensywy ${ }^{65}$. Aleksander Battenberg obawiając się, że sprzeciw może mieć poważne następstwa międzynarodowe, jeszcze tego samego dnia przerwał działania wojenne i zgodził się na podpisanie rozejmu ${ }^{66}$.

Tymczasem unia bułgarska i następujące po niej wydarzenia zaostrzyły rywalizację wielkich mocarstw na Bałkanach, co miało istotny wpływ na sytuację wewnętrzną w Bułgarii i zmiany na scenie politycznej. Najgłębsze zaszły w podzielonym już w 1883 r. obozie liberalnym. Bezpośrednio po zjednoczeniu „cankowiści” połączyli się z częścią liberałów z Rumelii Wschodniej, a wkrótce potem wchłonęli także prorosyjsko nastawionych działaczy tamtejszego obozu konserwatywnego z Marko Bałabanowem i Todorem Burmowem na czele, tworząc ugrupowanie o jednoznacznie prorosyjskim nastawieniu. W tym czasie druga frakcja liberałów, skupiona wokół Petko Karawełowa, do którego dołączyli Stefan Stambołow i Wasił Radosławow, zaczęła skłaniać się ku współpracy z mocarstwami zachodnimi, a zwłaszcza z Austro-Węgrami i Wielką Brytanią. Poza nimi na bułgarskiej scenie politycznej po zjednoczeniu z Rumelią Wschodnią działali jeszcze dawni konserwatyści z Księstwa z Konstantinem Stoiłowem i Grigorem Naczowiczem na czele, sympatyzujący z nimi rumelijski obóz konserwatywny Iwana Ewstratiewa Geszowa oraz niezależni politycy o orientacji prorosyjskiej.

Taki układ stosunków wewnętrznych w Bułgarii z dużym zaniepokojeniem przyjmowany był w Rosji. Dlatego też rząd carski nasilił zakulisowe działania na rzecz aktywizacji bułgarskich „rusofilów”. Trafiły one na podatny grunt, ponieważ środowiska te od dłuższego czasu stały na stanowisku, że główną przeszkodę w restauracji bliskich związków z Petersburgiem stanowi Aleksander Battenberg, a jednocześnie coraz wyraźniej opowiadały się one za usunięciem go z bułgarskiego tron ${ }^{67}$ i opracowywały plan działania $w$ tej kwestii, który po przeprowadzonych konsultacjach i uzyskaniu akceptacji rosyjskiej dyplomacji zdecydowano się wdrożyć w życie ${ }^{68}$. W nocy z 20 na 21 sierpnia 1886 r., wykorzystując nieobecność

${ }^{65}$ J. Grzegorzewski, Rok przewrotów..., s. 82; E. Lipnicki, Sprawa bułgarska..., s. 378; R. von Mach, op. cit., s. 330 .

${ }^{66}$ Wojnę zakończył traktat pokojowy, podpisany w Bukareszcie 3 marca $1886 \mathrm{r}$. Tekst dokumentu w: J. Rubacha, A. Malinowski, A. Giza, Historia Bułgarii 1870-1915. Materiały źródłowe z komentarzami, t. 1: Polityka międzynarodowa, Warszawa 2006, s. 62.

67 J. Grzegorzewski, Rok przewrotów..., s. 123; Е. Стателова, op. cit., s. 206-215; Е. Стателова, P. Попов, В. Танкова, op. cit., s. 93.

${ }^{68}$ Jak pisał Grzegorzewski, w opublikowanych dokumentach z toczącego się po nieudanym przewrocie śledztwa stwierdzano m.in.: „major Grujew zeznał, że w końcu lipca Cankow często odwiedzał agencyę dyplomatyczną rosyjską (w Sofii), gdzie go zapewniano, że w razie detronizacji księcia, Bułgarya jest zagwarantowaną od okupacyi i interwencyi zewnętrznej, na dowód czego pokazywano mu korespondencye od rządu rosyjskiego", idem, Rok przewrotów..., s. 123; na 
w Sofii oddziałów wojskowych wiernych Battenbergowi ${ }^{69}$, spiskowcy otoczyli pałac książęcy $^{70}$, aresztowali Aleksandra i zażądali podpisania aktu abdykacji ${ }^{71}$. Mimo początkowego oporu, książę podpisał dokument, po czym został odeskortowany do pogranicznej miejscowości Rjachowo nad Dunajem ${ }^{72}$, przez którą opuścić miał Bułgarię. Jednocześnie spiskowcy przesłali do władz wojskowych w głównych miastach Bułgarii dwie depesze, w których informowali o zaistniałym fakcie ${ }^{73}$ oraz wzywali do złożenia przysięgi na wierność nowemu rządowi ${ }^{74}$. Realizacja zamiaru przejęcia kontroli nad armią natrafiła jednak na opór części wojskowych i polityków z Stambołowem na czele, którzy nie chcieli torować „rusofilom” drogi do przejęcia władzy $^{75}$. Mimo to spiskowcy kontynuowali działania, a licząc na wsparcie Rosji i bierną postawę społeczeństwa ${ }^{76} 21$ sierpnia doprowadzili do oficjalnej dymisji rządu Karawełowa, a w jego miejsce powołali gabinet z biskupem Klimentem jako premierem ${ }^{77}$. Taki stan rzeczy spowodował natychmiastową reakcję Stambołowa.

ten temat także: idem, Siedmiomiesięczna walka..., nr 1 (88), s. 253; Н. Станев, op. cit., s. 66; A. von Huhn, Aus bulgarischer Sturmzeit, Leipzig 1886, s. 12-14.

${ }^{69}$ J. Grzegorzewski, Siedmiomiesięczna walka..., nr 1 (87), s. 194; na ten temat także: Н. Станев, op. cit., s. 67; A. von Huhn, op. cit., 24; E. Lipnicki, Zjazd w Gasteinie i wypadki bułgarskie, „Biblioteka Warszawska” 1886, t. 4, s. 19.

70 J. Grzegorzewski, Rok przewrotów..., s. 128; E. Lipnicki, Zjazd w Gasteinie..., s. 18; A. von Huhn, op. cit., s. 32; N. Forbes, A.J. Toynboe, D. Mitrany, D.G. Hogarth, The Balkans. A History of Bulgaria, Serbia, Greece, Rumania, Turkey, Oxford 1915, s. 59; Е. Стателова, Р. Попов, B. Танкова, ор. cit., s. 93-95.

${ }^{71}$ J. Grzegorzewski, Stronnictwa bułgarskie za Aleksandra Battenberga..., s. 141; na ten temat także: idem, Rok przewrotów..., s. 128; P. Malinowski, Militaryzm współczesny, „Ateneum” 86 (1897), t. 2, s. 417; C. Jireček, op. cit., s. 354.

72 J. Grzegorzewski, Rok przewrotów..., s. 129-130, 132, 157; E. Lipnicki, Zjazd w Gasteinie..., s. 18; A. von Huhn, op. cit., s. 35.

73 J. Grzegorzewski, Rok przewrotów..., s. 139; idem, Siedmiomiesięczna walka..., nr 1 (87), s. 192; na ten temat także: idem, Rok przewrotów..., s. 139; A. von Huhn, op. cit., s. 55.

${ }^{74}$ W skład tego gabinetu wchodzić mieli: P. Karawełow, S. Stambołow, D. Cankow, T. Burmow, Todor Ikonomow, Konstantin Weliczkow, Michaił Madżarów, W. Radosławow, K. Stoiłow, D. Grekow oraz Konstantin Nikiforow. Jak słusznie podkreśla Grzegorzewski, w momencie wysłania depeszy gabinet ten jeszcze nie istniał, a w rzeczywistości nigdy nie powstał. Konsultacje na temat jego utworzenia rozpoczęto dopiero kilka godzin później, a w ich trakcie okazało się, że nie zamierzają go współtworzyć: Grekow, Stoiłow, Karawełow i Nikiforow. Jednocześnie wrogo do samego zamachu i idei włączenia jego osoby do nowego rządu odniósł się, przebywający w tym czasie w Płowdiwie, Stambołow; J. Grzegorzewski, Siedmiomiesięczna walka..., nr 1 (87), s. 192-193.

75 Д. Маринов, ор. cit., т. 1, s. 272-336.

76 Jak pisał Grzegorzewski: „Przewrotowcy i ich stronnicy, jak pierwszego dnia liczyli przedstawienia dzieła swego jako aktu woli narodu, tak znów po sformowaniu nowego rządu i ujawnieniu się pierwszych protestów, kierowali się na dyscyplinę armii i bierność ludu i zgodzenie się jego z faktem już dokonanym”, idem, Siedmiomiesięczna walka..., nr 1 (87), s. 193.

77 J. Grzegorzewski, Rok przewrotów..., s. 142; idem, Siedmiomiesięczna walka..., nr 1 (87), s. 192; idem, Dragan Cankow..., s. 358-359; W.R. Wegnerowicz, Odrodzenie Bułgaryi, „Literatura i Sztuka. Dodatek do Dziennika Poznańskiego" 2 (1913); A. von Huhn, op. cit., s. 67. Rząd ten tworzyli poza Kilmentem: K. Nikiforow, D. Canokow, Christo Stojanow, W. Radosławow, K. Weliczkow i T. Burmow. 
Jako przewodniczący Zgromadzenia Narodowego nawiązał on kontakt z grupą nieuznających zmian wojskowych z ppłk. Sawą Mutkurowem na czele, których wezwał do przybycia do Sofii z wiernymi im oddziałami ${ }^{78}$, a dwa dni później ogłosił odezwę, w której zawiadamiał, że zamach stanu przeprowadzony został z naruszeniem prawa i odmawiał legalności utworzonemu przez spiskowców rządowi ${ }^{79}$. Dzięki temu udało się opanować sytuację w stolicy ${ }^{80}$. Dążąc do przywrócenia stanu sprzed przewrotu, zwolennicy Battenberga wysłali do niego telegram, w którym wzywali go do powrotu do kraju ${ }^{81}$. Wychodząc naprzeciw tym oczekiwaniom Aleksander podjął decyzję o powrocie do Bułgarii. Mimo owacyjnego powitania, które zgotowali mu społeczeństwo i nowy gabinet Radosławowa ${ }^{82}$, zdawał on sobie sprawę z faktu, że jego pozycja, głównie z powodu negatywnego stosunku Rosji do ponownego objęcia przez niego władzy w Bułgarii, jest słaba. Dlatego też bezpośrednio po przybyciu do Ruse 28 sierpnia wysłał do Aleksandra III depeszę, w której informował go o powrocie do Bułgarii i prosił cara o wsparcie w walce $\mathrm{z}$ inicjatorami zamachu stanu, ale jednocześnie deklarował, że jest gotowy ustąpić $\mathrm{z}$ tronu, o ile Rosja sobie tego zażyczy ${ }^{83}$. Odpowiedź cara pozbawiła go jednak złudzeń, że uda mu się zatrzymać tytuł księcia Bułgariii ${ }^{84}$. Dlatego też 7 września

${ }^{78}$ J. Grzegorzewski, Rok przewrotów..., s. 149; idem, Siedmiomiesięczna walka..., nr 1 (87), s. 194195; E. Lipnicki, Zjazd w Gasteinie..., s. 24.

79 Tekst odezwy w: J. Grzegorzewski, Siedmiomiesięczna walka..., nr 1 (87), s. 200; E. Lipnicki, Zjazd w Gasteinie..., s. 24; na ten temat także: Н. Станев, op. cit., s. 70; A. von Huhn, op. cit., s. 91; А. Цураков, op. cit., s. 55. Efektem tych działań było wycofanie się z rządu Klimenta kilku ministrów. W związku z tym, 24 sierpnia 1886 r. powołany został nowy, koalicyjny gabinet pod kierownictwem Karawełowa, który upadł jednak po zaledwie czterech dniach; J. Grzegorzewski, Siedmiomiesięczna walka..., nr 1 (87), s. 202; A. von Huhn, op. cit., s. 77; С. Грънчаров, Русофилските политически сили в България (август 1886-август 1887 г.), „Известия на Института за история” 26 (1983), s. 127.

80 J. Grzegorzewski, Stronnictwa bułgarskie za Aleksandra Battenberga..., s. 203; na ten temat także: idem, Rok przewrotów..., s. 139-152.

81 J. Grzegorzewski, Rok przewrotów..., s. 161-162; A. von Huhn, op. cit., s. 94-95.

82 J. Grzegorzewski, Rok przewrotów..., s. 165-167; idem, Siedmiomiesięczna walka..., nr 1 (87), s. 206; C. Jireček, op. cit., s. 355; A. von Huhn, op. cit., s. 158.

83 J. Grzegorzewski, Rok przewrotów..., s. 168; A. von Huhn, op. cit., s. 131-132. A. Piotrowski, naoczny świadek wydarzeń w Bułgarii w 1886 r., bardzo krytycznie oceniał decyzję o wysłaniu depeszy do cara. W artykule zamieszczonym w „Tygodniku Illustrowanym” w 1908 r. napisał: „Był to najgrubszy błąd, jaki popełnił książę Aleksander”; A. Piotrowski, Z dziejów Carstwa Bułgarskiego. Wspomnienia osobiste, "Tygodnik Illustrowany” 42 (1908), s. 847; na ten temat także: C. Jireček, op. cit., s. 355; E. Lipnicki, Zjazd w Gasteinie..., s. 25; N. Forbes, A.J. Toynboe, D. Mitrany, D.G. Hogarth, op. cit., s. 59; A. von Huhn, op. cit., s. 99, 108.

${ }^{84}$ J. Grzegorzewski, Rok przewrotów..., s. 168; idem, Siedmiomiesięczna walka..., nr 1 (87), s. 205; A. von Huhn, op. cit., s. 132. Zaważyły na tym także opinie innych mocarstw w tej kwestii. Jak pisał Grzegorzewski: „Drugim momentem decydującym dla księcia była depesza Bismancka, ilustrująca depeszę cara i wyraźnie dająca już do zrozumienia konieczność abdykacyi. Francja, już wówczas kokietująca Rosyę, była zupełnie, jak Bismarck, po jej stronie. Kalnoky zachowywał się obojętnie, mając wzrok skierowany ku Bismarckowi. Włochy to samo rezerwowe zachowywały stanowisko. Jeden gabinet angielski, częścią z przekonania, część w myśl życzeń królowej 
1886 r., po przekazaniu władzy w ręce rady regencyjnej, dobrowolnie opuścił Bułgarię na zawsze ${ }^{85}$.

Wyjazd Aleksandra Battenberga nie rozwiązał jednak trudnej sytuacji w Bułgarii ${ }^{86}$. Tym samym pierwszoplanowym zadaniem stojącym przez radą regencyjną, tworzoną przez Stambołowa, Karawełowa i Mutkurowa ${ }^{87}$, był problem normalizacji stosunków w kraju i wybór nowego monarchy. Do działań w tych obszarach przystąpiono $\mathrm{z}$ dużym zaangażowaniem, co podyktowane było przede wszystkim niepokojącymi wiadomościami z Petersburga. Jakkolwiek z zadowoleniem przyjęto tam abdykację Aleksandra, to zarówno w prasie ${ }^{88}$, jak i wśród polityków narastało niezadowolenie $\mathrm{z}$ utrzymania się $\mathrm{u}$ władzy w Bułgarii antyrosyjsko nastawionych kręgów politycznych. Dobitnie wyraził to rosyjski konsul w Widiniu Jurij Karcow stwierdzając: „Cóż za pożytek z tego, że Batenberga niema tu [...], skoro jego kreatury pozostały i cała władza w ich rękach" ${ }^{89}$. Dlatego też już w połowie września 1886 r. ze specjalną misją do Bułgarii przybył gen. Nikołaj Kaułbars ${ }^{90}$, który zgodnie $\mathrm{z}$ otrzymanymi w Petersburgu wytycznymi ${ }^{91}$ podjął działania na rzecz wzmocnienia opozycji antyrządowej ${ }^{92}$. Realizując te zadania zażądał od rady regencyjnej zniesienia stanu wyjątkowego i uwolnienia aresztowanych uczestników spisku przeciw księciu Aleksandrowi ${ }^{93}$, a także odroczenia wyborów do Wielkiego Zgromadzenia Narodowego ${ }^{94}$, które miało dokonać wyboru nowego bułgarskiego

Wiktoryi, występował stanowczo, żądając utrzymania się księcia na tronie, ale prócz moralnego poparcia, nie przyrzekając żadnego materyalnego"; J. Grzegorzewski, Siedmiomiesięczna walka..., nr 1 (87), s. 204.

85 J. Grzegorzewski, Rok przewrotów..., s. 169, 188-194 i n.; idem, Siedmiomiesięczna walka..., nr 1 (87), s. 205-206; N. Forbes, A.J. Toynboe, D. Mitrany, D.G. Hogarth, op. cit., s. 59; A. von Huhn, op. cit., s. 158; А. Цураков, op. cit., s. 62.

${ }^{86}$ J. Grzegorzewski, Siedmiomiesięczna walka..., nr 1 (87), s. 206.

87 Ibidem; W.R. Wegnerowicz, op. cit.; C. Грънчаров, op. cit., s. 137.

${ }^{88}$ Cytując jedną z rosyjskich gazet Grzegorzewski pisał: „Najsnadniejsze rozwiązanie obecnego przesilenia wschodniego przedstawia się $\mathrm{w}$ postaci rosyjskiej okupacji w Bułgaryi, ku czemu ogólna sytuacja wielce sprzyja”, idem, Siedmiomiesięczna walka..., nr 1 (87), s. 207.

89 Ibidem.

90 J. Grzegorzewski, Rok przewrotów..., s. 239; idem, Siedmiomiesięczna walka..., nr 1 (88), s. 250; W.R. Wegnerowicz, op. cit.; Д. Маринов, op. cit., т. 2, s. 8-16, 20-34; A. von Huhn, op. cit., s. 219-264. Nikołaj był bratem Aleksandra Kaułbarsa, byłego ministra wojny w rządzie L. Sobolewa.

91 J. Grzegorzewski, Rok przewrotów..., s. 221; idem, Siedmiomiesięczna walka..., nr 1 (88), s. $250-251$.

92 Външната политика.., т. 2, s. 106-107, 110.

93 Ibidem, т. 2, s. 95. Uczestnicy spisku zostali ostatecznie uwolnieni z końcem października 1886 r. na wyraźną prośbę Bismarcka, który w związku z silnym zaangażowaniem Austro-Węgier w sprawy bałkańskie starał się uniknąć zatargów z Rosją na tle bułgarskim; J. Grzegorzewski, Siedmiomiesięczna walka..., nr 1 (89), s. 352; Н. Станев, op. cit., s. 75-76; na ten temat także: Външната политика..., т. 2, s. 106-107.

94 J. Grzegorzewski, Siedmiomiesięczna walka..., nr 1 (88), s. 251; A. Piotrowski, op. cit., s. 847; С. Грънчаров, op. cit., s. 139. 
monarchy. Władze bułgarskie odniosły się do tych żądań negatywnie, a ostatecznie podjęły decyzję o rozpisaniu wyborów parlamentarnych ${ }^{95}$.

W odpowiedzi Kaułbars udał się w podróż po Bułgariii" ${ }^{96}$ w trakcie której zamierzał prowadzić aktywną antywyborczą agitację wśród mieszkańców miast i wsi, a zwłaszcza wśród oficerów prowincjonalnych garnizonów. Efekt tych działań był jednak raczej skromny, chociaż w kilku miejscach doszło do krwawych rozruchów. Przebieg zajść w Dupnicy prezentował Grzegorzewski pisząc:

Podszczuty tłum chłopów z hasłem „Neczeme izbori, sakame Rusija, Rusija danyk nie wzima" (nie chcemy wyborów, pragniemy Rosyi, Rosya podatków nie ściąga), rzucił się na komisyę wyborczą, potem na komisaryat, skąd wywleczono naczelnika powiatu, Dymitrowa, wleczono go, bitego, za nogi po bruku i wśród wycia „da żywieje ruskija car”, wrzucono konającego w rzekę, urągając nadto trupowi. Zaczem pijana tryumfem tłuszcza napadła w jednej ze szkół posłów sejmowych Zografa i Grynczarowa, tudzież nauczyciela Papukczyjskiego, zrzucono ich z piętra na bruk głowami w dół i dobito maczugami, Grynczarowowi nadto wbito noże w głowę i brzuch rozpruto ${ }^{97}$.

Incydenty te spotykały się jednak z szybkimi i stanowczymi działaniami sił porządkowych i wojska, które siłą zaprowadzały porządek i aresztowały winowajców. Tym samym, mimo wysiłków Kaułbarsa, wybory zostały przeprowadzone, ale nie oznaczało to zakończenia rosyjskiej agitacji w Bułgarii i lokalnie wybuchających rozruchów ${ }^{98}$. Jednocześnie, 24 października 1886 r., na tydzień przed inauguracyjnym posiedzeniem parlamentu, poselstwo rosyjskie w Sofii przekazało rządowi bułgarskiemu notę, w której zawiadamiano, że Rosja uznaje Zgromadzenie za nielegalne, a tym samym nie będzie respektować podjętych przez nie decy$\mathrm{zji}^{99}$. W następnych dniach pojawiły się natomiast informacje o planowanej przez Petersburg zbrojnej interwencji w Bułgarii ${ }^{100}$. Informacje te mocno niepokoiły radę regencyjną, ale nie przeszkodziły w wyborze 10 listopada $1886 \mathrm{r}$. na tron bułgarski duńskiego królewicza Waldemara ${ }^{101}$. Jakkolwiek ten odmówił przyjęcia korony, jasne stało się, że dotychczasowe działania Kaułbarsa nie dały żadnych rezultatów i w żaden sposób nie wpłynęły na podejmowane przez Bułgarów decyzje. W związku z tym 20 listopada rosyjski dyplomata opuścił Sofię, a rząd carski zerwał stosunki dyplomatyczne $\mathrm{z}$ Bułgarią ${ }^{102}$. W tej sytuacji zagrożenie interwencją

\footnotetext{
95 J. Grzegorzewski, Siedmiomiesięczna walka..., nr 1 (88), s. 251.

${ }^{96}$ Ibidem, s. 254-258; idem, Rok przewrotów..., s. 253.

97 J. Grzegorzewski, Siedmiomiesięczna walka..., nr 1 (88), s. 259-260.

98 Ibidem, s. 352-353.

99 J. Grzegorzewski, Rok przewrotów..., s. 247.

100 J. Grzegorzewski, Siedmiomiesięczna walka..., nr 1 (89), s. 351-352.

101 Ibidem, s. 355; na ten temat także: C. Jireček, op. cit., s. 356; Д. Маринов, ор. cit., т. 2., s. 34-56.

102 J. Grzegorzewski, Rok przewrotów..., s. 260; idem, Siedmiomiesięczna walka..., nr 1 (89), s. 356; P. Malinowski, op. cit., s. 417; na ten temat także: C. Jankowski, Na gruzach Turcji. Zarysy historyczno-publicystyczne, Warszawa 1915, s. 176; А. Цураков, ор. cit., s. 62.
} 
rosyjską znacznie wzrosło, a prowadzona nadal przez rosyjskich agentów agitacja destabilizowała sytuację wewnętrzną. Mnożyły się także różnego rodzaju spiski i wystąpienia, z których największe rozmiary osiągnęło antyrządowe wojskowe powstanie w Ruse i Silistrze w marcu 1887 r. ${ }^{103}$ Zostało ono jednak szybko stłumione, a stojący na jego czele oficerowie aresztowani i skazani na karę śmierci ${ }^{104}$.

Niestabilna sytuacja w kraju skłaniała radę regencyjną do podejmowania działań na rzecz jak najszybszej jej zmiany, a największe nadzieje wiązano $\mathrm{z}$ wyborem nowego monarchy. Dlatego też już pod koniec listopada 1886 r. w podróż po Europie wysłana została delegacja złożona z Konstantina Stoiłowa, Dimityra Grekowa i Konstantina Kałczewa ${ }^{105}$, której celem było znalezienie odpowiedniego kandydata. Jak pisał Grzegorzewski:

Niedopuszczona do Petersburga, a chłodno i prywatnie podjęta w Berlinie i Paryżu, u Kalnokyego półoficjalnie, witana wszędzie przez publiczność w Europie z ciekawością, w Peszcie, Wiedniu, Rzymie i Londynie sympatycznie i nawet entuzyastycznie, delegacja doznała największego poparcia u Robillanta [Carlo Felice Nicolis, conte di Robilant] włoskiego i Iddesleya [Stafford Henry Northcote, 1st Earl of Iddesleigh] angielskiego ${ }^{106}$.

Wszędzie jednak doradzano Bułgarom powściągliwość w działaniach oraz zwracanie uwagi na stanowisko rosyjskie. Tymczasem Petersburg odrzucał możliwość jakichkolwiek dyskusji w tej kwestii i stał na stanowisku, że zgłoszona przez Rosję kandydatura księcia Mingrelii Mikołaja jest ostateczna ${ }^{107}$. W związku ze sztywnym stanowiskiem rządu rosyjskiego w tej kwestii, władze bułgarskie nabrały przekonania, że jedyną przeciwwagę dla jego osoby mógł stanowić wyłącznie kandydat cieszący się poparciem monarchii habsburskiej. W związku z tym zdecydowano się zwrócić większą uwagę na osobę księcia Ferdynanda Sachsen-Coburg und Gota, którego Austriacy wskazali podczas pobytu delegacji w Wiedniu ${ }^{108}$. Zgodnie z przewidywaniami jego kandydatura natrafiła na stanowczy opór Rosji, a swoje zastrzeżenia wyraziła także Turcja. Ta ostatnia dopuszczała jednak podjęcie wstępnych konsultacji na temat wskazanego przez stronę bułgarską kandydata, choć zastrzegała, że przy podejmowaniu ostatecznej decyzji będzie się kierować stanowiskiem Petersburga. Mimo to rozmowy z rządem tureckim podjęli poseł bułgarski w Konstantynopolu Georgi Wyłkowicz oraz wysłany do tureckiej

103 J. Grzegorzewski, Siedmiomiesięczna walka..., nr 1 (89), s. 364-368; na ten temat także: A. Piotrowski, op. cit., s. 847-848; Д. Маринов, op. cit., т. 2, s. 72-86 і 102-124; С. Грънчаров, op. cit., s. 145.

104 J. Grzegorzewski, Siedmiomiesięczna walka..., nr 1 (89), s. 368.

105 Ibidem, s. 357.

106 Ibidem.

107 Strona bułgarska kandydaturę tę zdecydowanie odrzucała, a Stambołow komentował ją sarkastyczną uwagą, że „Bułgarya nie może wybrać księcia tego, gdyż traktat berliński zabrania przesiedlenia Czerkiesów do Bułgaryi”, ibidem.

108 J. Grzegorzewski, Stronnictwa bułgarskie po przewrotach..., nr 2 (95), s. 768. 
stolicy Dragan Cankow ${ }^{109}$. Nie przyniosły one jednak żadnych rezultatów i wkrótce zostały przerwane ${ }^{110}$.

Tymczasem przybierający na sile kryzys wewnętrzny zmusił radę regencyjną do szybkiego działania. $Z$ jej inicjatywy 7 lipca 1887 r. parlament powołał Ferdynanda Coburga na bułgarski tron i wezwał go do przyjazdu do Sofii. Jego wybór spotkał się oczywiście ze sprzeciwem ze strony Rosji. Twarde stanowisko Petersburga w tej kwestii nie tylko uniemożliwiło uznanie przez wielkie mocarstwa Ferdynanda za bułgarskiego monarchę, ale także skłoniło Turcję - nominalnego zwierzchnika Księstwa Bułgarii - do odmowy zatwierdzenia decyzji Zgromadzenia Narodowego. Tym samym sytuacja obejmującego rządy Ferdynanda była niezwykle skomplikowana ${ }^{111}$, co utrudniało mu sprawowanie władzy i prowadzenie polityki zagranicznej. Rzeczywiste rządy w państwie sprawował Stambołow, który stanął na czele gabinetu ${ }^{112}$, a Coburg rozważał możliwość ustąpienia $\mathrm{z}$ urzędu ${ }^{113}$. W tym czasie nastąpiły także istotne zmiany na bułgarskiej scenie politycznej. Rozpadowi uległ obóz „karawelistów”, od którego odłączyli się politycy reprezentujący prozachodnie nastawienie ${ }^{114}$. Utworzyli oni dwa ugrupowania. Pierwsze z nich z Wasiłem Radosławowem na czele pod koniec 1887 r. przyjęło nazwę Klub Liberalny (Либерален клуб), a drugie, pod kierownictwem Stefana Stambołowa, przekształciło się w Partię Narodowo-Liberalną (Народнолиберална партия) i przez dłuższy czas stanowiło zaplecze polityczne rządu ${ }^{115}$. W działaniach politycznych ugrupowanie Stambołowa wspierali prezentujący podobne poglądy konserwatyści ze Stoiłowem na czele oraz konserwatyści rumelijscy Geszowa. Drugą stronę sceny politycznej tworzyli „cankowiści” i pozostali po rozpadzie „karaweliści”, którzy tworzyli opozycyjny obóz „rusofilski”.

Objęcie steru rządów przez Stambołowa, a zwłaszcza prowadzona przez niego polityka, stanowily - zdaniem Grzegorzewskiego - „epokowy przełom w życiu nowoczesnej Bułgaryi”"16. Szczególnie duże jego uznanie budziły działania, które

109 С. Грънчаров, op. cit., s. 140-141.

110 Външната политика..., т. 2, s. 234-237. Warto zaznaczyć, że strona bułgarska podjęła równocześnie konsultacje na temat zażegnania kryzysu wewnętrznego i powołania koalicyjnego, reprezentującego wszystkie ugrupowania polityczne rządu; J. Grzegorzewski, Siedmiomiesięczna walka..., nr 1 (89), s. 358-364.

111 J. Grzegorzewski, Stronnictwa bułgarskie po przewrotach..., nr 2 (95), s. 768; A. Piotrowski, op. cit., s. 847.

112 Rząd pod kierownictwem Stambołowa został utworzony 1 września 1887 r.; J. Grzegorzewski, Stronnictwa bułgarskie po przewrotach..., nr 2 (95), s. 763; C. Jireček, op. cit., s. 356. Zastąpił on gabinet Konstantina Stoiłowa, który ukonstytuował się po wyborze Ferdynanda na księcia Bułgarii.

113 F. Crispi, Memoiren, Berlin 1912, s. 277 i n.

114 C. Jireček, op. cit., s. 297.

115 Програми, програмни документи..., s. 114-115, 177. Ugrupowanie Radosławowa zmieniło w 1895 r. nazwę na Partia Liberalna (Либерална партия), a potocznie nazywano go „radosławistami”; partię Stambołwa określano potocznie „stambołowistami”.

116 J. Grzegorzewski, Stronnictwa bułgarskie po przewrotach..., nr 2 (95), s. 763. 
z jednej strony pozwoliły Bułgarii wyjść spod kurateli rosyjskiej, a z drugiej zbliżyły ją do mocarstw zachodnich ${ }^{117}$, a także podjęte wysiłki na rzecz wyrugowania z życia politycznego prorosyjskiej opozycji. Jednocześnie badacz zwracał uwagę na dokonania Stambołowa w polityce wewnętrznej, a zwłaszcza na: zmiany w konstytucji, rozwój bułgarskich sił zbrojnych, reformę szkolnictwa, zmiany w administracji i wielki ruch inwestycyjny, który „zbliżył Bułgaryę bardziej do życia europejskiego, niż była przed nim"118. Grzegorzewski pozytywnie odnosił się do metod sprawowania władzy, które już ówcześnie zyskały miano „reżimu”. Jak pisał: „Prawie ośmioletnie rządy jego przeszły jakby huragan druzgocący po drodze stare tamy i krzepkie dęby, a zalewający tę drogę pochodu swego powodzią ofiar krwawych, ale huraganem, który oczyścił atmosferę, ale powodzią, która pozostawiła namulisko żyzne posiewu przyszłości"119.

Nie ulega wątpliwości, że zakrojone na szeroką skalę działania „stambołowistów" zbliżyły Bułgarię do mocarstw zachodnich i znacząco wpłynęły na stabilizację sytuacji w kraju, lecz stworzenie sprzyjających warunków dla głębszej penetracji zachodnioeuropejskich kapitałów nie tylko rujnowało kluczowe sektory gospodarki, ale także zwiększało zadłużenie zewnętrzne państwa, a dyktatorskie metody rządów i blokowanie prób porozumienia z Rosją w miarę upływu czasu budziły coraz większe niezadowolenie społeczeństwa. Stąd też wiosną 1894 r. Ferdynand zdecydował się odsunąć Stambołowa od władzy ${ }^{120}$, a misję tworzenia nowego rządu powierzył Konstantinowi Stoiłowowi.

Upadek „reżimu stambołowskiego” rozpoczął niemal piętnastoletni okres dynamicznych przemian bułgarskiej sceny politycznej. Pierwszym jego aktem było utworzenie jeszcze w 1894 r. Partii Narodowej (Народна партия), potocznie nazywanej „narodniakami”, która powstała ze zjednoczenia konserwatystów pod przewodnictwem Stoiłowa i dawnego rumelijskiego obozu konserwatywnego z Geszowem i Iwanem Wazowem na czele ${ }^{121}$. W latach kolejnych cechą charakterystyczną zmian na bułgarskiej scenie politycznej było stopniowe zbliżanie się programów poszczególnych ugrupowań. Jak pisał Grzegorzewski: „Rusofilstwo i rusofobstwo będące za Stambułowa zasadami obozów, zwinęly teraz sztandary swoje, jak się zwija w pochwę chorągwie pułkowe dla przechowania ich w pałacu monarchy, a wydobycia onych stamtąd w przygodnej okoliczności”'122. Jednocześnie

117 Warto podkreślić, że Grzegorzewski w swych pracach wielokrotnie manifestował swoje antyrosyjskie nastawienie, co niewątpliwie było pochodną poglądów przeważającej części ówczesnego galicyjskiego świata naukowego, z którym utrzymywał bliskie kontakty. Poglądy te znacząco wpływały na formułowane przez niego tezy, a czasami prowadziły do bezrefleksyjnej nadinterpretacji prezentowanych faktów. Szczególnie widoczne jest to w bezkrytycznej ocenie działań Stambołowa, które do dziś stanowią pole do dyskusji w bułgarskim świecie naukowym.

118 J. Grzegorzewski, Stronnictwa bułgarskie po przewrotach..., nr 2 (95), s. 763.

119 Ibidem, s. 764.

120 Ibidem, s. 768.

121 Ibidem, s. 766.

122 Ibidem, s. 769. 
stabilizacja sytuacji wewnętrznej, a zwłaszcza chwilowy spadek napięcia na arenie międzynarodowej, pozwalały Ferdynandowi prowadzić politykę niezależną od haseł i ideologii bułgarskich partii.

Sprawy wojskowe i politykę zagraniczną pozostawił wyłącznie sobie i odnośne teki w gabinetach powierza bez względu na będące u władzy stronnictwo osobom bezpartyjnym, osobiście zaufanym i osobiście od niego zależnym. We wszystkich innych sprawach pozostawia wolną ręką panującemu stronnictwu interweniując tylko wtedy, gdy akcya przeszkadza pewnym jego planom, lub gdy uznał czas władzy tegoż stronnictwa za dostateczny, aby ustąpić miejsca innemu ${ }^{123}$.

Taki stan rzeczy sprawiał, że na dalsze zmiany tylko w ograniczonym zakresie wpływ miały kwestie ideologiczne, a częściej były one powodowane osobistymi ambicjami poszczególnych liderów lub były wynikiem krystalizowania się i wzrostu świadomości politycznej upośledzonych do tej pory w tym obszarze grup społecznych lub zawodowych.

W 1899 r. doszło do rozpadu w łonie „narodniaków”, od których oderwała się frakcja pod przywództwem Konstantina Weliczkowa. Połączyła się ona Z „cankowistami”, a ugrupowanie przyjęło nazwę Partia Postępowo-Liberalna (Прогресивнолибералната партия). Z kolei w 1903 r. z obozu „karawelistów” którzy od 1896 r. używali nazwy Partia Demokratyczna (Демократическа партия) wystąpiła grupa działaczy z Todorem Włajkowem i Naiczo Canowem na czele, która dwa lata później utworzyła Partię Radykalno-Demokratyczną (Радикалдемократическа партия). Rozłamy nie ominęły także „radosławistów”. W 1904 r. ich szeregi opuściła frakcja Dymityra Tonczewa, która przekształciła się w Partię Młodo-Liberalną (Младолиберална партия). W tym czasie zachodziły też procesy przeciwne. Pod koniec lat dziewięćdziesiątych XIX w. nastąpiła konsolidacja rozproszonej po śmierci Stambołowa Partii Narodowo-Liberalnej, na czele której stanął Dimityr Petkow. Aktywizowały się także środowiska robotnicze i chłopskie. W 1894 r. w wyniku zjednoczenia dwóch istniejących wcześniej organizacji - Bułgarskiej Partii Socjaldemokratycznej (Българска социалдемократическа партия) i Bułgarskiego Związku Socjaldemokratycznego (Български социалдемократически съюз) została utworzona Bułgarska Robotnicza Partia Socjaldemokratyczna (Българска работническа социалдемократическа партия). Ta jednak już w 1903 r. rozpadła się na dwa niezależne i antagonistycznie do siebie nastawione ugrupowania, używające tej samej nazwy. Lewe skrzydło z Dimityrem Błagoewem na czele utworzyło BRPSD „ciasnych socjalistów” (БРСДП - тесни социалисти), określaną potocznie mianem „tesniaków”. Prawica ugrupowania, skupiona wokół Janko Sakyzowa, stworzyła natomiast partię, która przyjęła nazwę BRPSD „szerocy socjaliści” (БРСДП - широки социалисти). W ostatnich dniach grudnia 1899 r. swoje ugrupowanie pod nazwą Bułgarski Związek Chłopski (Български земеделски

${ }^{123}$ Ibidem, s. 769-770. 
съюз) z Janko Zabunowem na czele stworzyli także chłopi. Początkowo posiadał on charakter związku zawodowego, ale na początku 1901 r. przekształcił się w partię polityczną - Bułgarski Ludowy Związek Chłopski (Български земеделски народен съюз $)^{124}$.

Klasyfikując bułgarskie ugrupowania przez pryzmat ich programów politycznych, Grzegorzewski stworzył schemat, w którym, jego zdaniem, „socyaliści, radykali i agraryusze musieliby być zaliczeni do lewicy, skrajnej dla pierwszych, umiarkowanej dla ostatnich; progresywno-liberalni i narodniacy - tworzyliby prawicę ze skrajnem odcieniem dla drugich; pozostali - liberali, narodowo-liberalni, młodo-liberalni i demokraci stanowiliby środek - centrum"125, ale od razu zaznaczył, że schemat ten „nie zupełnie odpowiada rzeczywistości praktycznej” ${ }^{126}$. Specyfiką bułgarskich ugrupowań było bowiem tworzenie możliwie szerokich programów, co podyktowane było chęcią pozyskania jak największej grupy wyborców i stworzenia odpowiedniej bazy dla agitacji i walki politycznej. Często wynikało to także z braku doświadczenia i nieznajomości prawa. Tym samym większość deklaracji była dla ugrupowań wspólna ${ }^{127}$, składane obietnice rzadko realizowane w szerszym wymiarze, kwestią najistotniejszą było przejęcie władzy, chociaż - w związku ze wspomnianą wyżej polityką księcia - nie zawsze było to pochodną programu czy prezentowanej aktywności. Taki stan rzeczy kreował specyficzny obraz wyborów parlamentarnych. Jak pisał Grzegorzewski:

Tak bywa nietylko w Bułgaryi, ale pono i gdzieindziej: każda partya dąży do władzy i pragnie ją posiąść, wyjątków pod tym względem niema. Różnica w tem tylko, że gdy w państwach silnie rozwiniętych konstytucyjnie większość parlamentu wyszła z wyborów staje się rządzącą i zdobywa, w Bułgaryi przeciwnie - stronnictwo powołane do władzy, choćby przedtem posiadało tylko kilka głosów w sejmie, w wyborach zarządzonych przez siebie zdobywa większośćc ${ }^{128}$.

Efektem takiego stanu rzeczy był także fakt, że po wyborach obywatele cieszyli się relatywnie niewielkim szacunkiem polityków, a ich prawa były często naruszane.

Nigdzie w Europie - pisał Grzegorzewski - nie jest minister tak wszechwładnym panem losu obywateli na stanowiskach urzędowych, jak w Bułgaryi. [...] Od wyroków jego niema apelacyi, istniejącej nawet w Rosyi do senatu. Stanowisko to jego da się chyba porównać

124 Ibidem, s. $772-775$.

125 Ibidem, s. 775.

126 Ibidem.

127 Obrazując tę sytuację Grzegorzewski pisał: „Poza chwilowymi i okolicznościowymi programami, wszystkie cztery partie liberalne w zasadach swych społecznych nieczem się nie różnią, jak nie różnili się starsi ich przedstawiciele od macierzy swej cankowistowskiej. Co do tego lub owego punktu zasad powstają niekiedy między nimi spory, które wszakże mają bardziej znaczenie scholastyczne, niż teoretyczne i praktyczne", ibidem, s. 776.

128 Ibidem, s. 770. 
ze stanowiskiem wezyra w starej Turcyi, z tą różnicą, że takim wezyrem jest w Bułgaryi każdorazowy minister każdej teki ${ }^{129}$.

Ale w wyborach walczono nie tylko o posady ministerialne. Zwycięstwo gwarantowało bowiem stanowiska $\mathrm{w}$ całej administracji państwowej, które traktowano jako typowy „łup wyborczy”. Tak zwany „kadryl partyjny” 130 obejmował urzędników wszystkich szczebli i profesji - od policjantów-stójkowych na ulicach po dyrektorów szkół i przedsiębiorstw państwowych, od zamiatacza po prezesa trybunału kasacyjnego. $\mathrm{W}$ tej rotacji kadrowej nie brano pod uwage ani predyspozycji czy wykształcenia, ani sytuacji osobistej zwalnianego pracownika. Sytuację tę Grzegorzewski mocno krytykował, widząc w niej zagrożenie dla państwa i społeczeństwa ${ }^{131}$.

Nie ulega natomiast wątpliwości, że kolejne gabinety bułgarskie dokładały starań, aby w możliwie szybkim tempie zewnętrznie upodobnić Bułgarię do innych państw europejskich. Nie szczędzono na ten cel sił i środków, nie przywiązując uwagi do faktu, że znaczna część tych ostatnich pochodziła z pożyczek i kredytów, najczęściej zagranicznych. Inspirowały je do tego nowe potrzeby i pragnienia, które stały się udziałem bułgarskiego społeczeństwa po odzyskaniu niepodległości ${ }^{132}$. Jednocześnie wiele obszarów było niedoinwestowanych lub w ogóle pozbawionych środków finansowych ${ }^{133}$.

Dzieje polityczne Bułgarii w ostatnim ćwierćwieczu XIX stulecia były niezwykle skomplikowane. Odzyskanie niepodległości postawiło przed młodym państwem wiele zadań, które stworzyć miały fundamenty państwowości i zapewnić poczesne miejsce $\mathrm{w}$ Europie. Jednym $\mathrm{z}$ nich były działania w obszarze polityki zarówno w wewnętrznym, jaki i międzynarodowym wymiarze. Ten złożony proces obserwował, opisywał i komentował Jan Grzegorzewski, bez którego prac zrozumienie poszczególnych jego elementów byłoby utrudnione.

129 Ibidem, s. 777.

130 Ibidem, nr 2 (96), s. 817.

131 Ibidem, s. 818.

132 Ibidem, nr 2 (95), s. 782. Znacząco zmienił się wygląd głównych miast, a szczególnie Sofii, powstawały nowe obiekty użyteczności publicznej, cerkwie, wodociągi itp. Jednocześnie jednak zachodziły w Bułgarii nieznane wcześniej procesy. Charakteryzując je Grzegorzewski pisał m.in.: „Chłopaki szkolne po szynkach i kawiarniach ćwiczą swe siły płciowe na zwierzętach i ptakach lub na wybrzeżach morskich urządzają publicznie Sodomę i Gomorę, to znów przed własną szkołą w hazardowe rzucanie kości [...], a na uwagę przechodnia grożą mu pięściami lub odpędzają kamieniami, gdy w tej samej chwili nauczyciele zebrani w szkole odmawiają wszelkiej interwencyi, powiadając, że ich rzeczą nauka, nie wychowanie na ulicy; szpitale macierzyńskie („majczyn-dom”) dla ubogich położnic zapełniają się 14-letnimi uczennicami gimnazyów żeńskich; a młody uniwersytet debiutuje nie tylko oklaskiwaniem tych spektaklów, ale i urządzaniem flirtów organizacyami partyjnemi słuchaczów i słuchaczek w imię konstytucyjnej wolności obywatelskiej i autonomii akademickiej", ibidem, nr 2 (96), s. 815

133 Ibidem, nr 2 (96), s. 819-820. 


\title{
Bulgarians and Bulgaria in the last quarter of the $19^{\text {th }}$ century in the publications of Jan Grzegorzewski (internal policy, foreign policy)
}

\begin{abstract}
The period of five-century "Turkish yoke" of the Bulgarian lands brought up many deep and multifaceted changes in almost all areas of social life. The Bulgarian population, pushed aside on the margin of social life and deprived of almost all public rights, were unable to reconstruct their elites, destroyed physically and ideologically during the Turkish invasion of the Balkans. And it was for this reason that on the threshold of independence the Bulgarians had only a handful of people prepared to lead the nation and to perform a public service both on a local and national scale. The issue became especially important after Bulgaria regained its statehood in 1878, and social and economic problems of the young state were aggravated by the rivalry of the great powers fighting for influence in this part of Europe, which effectively attracted the attention of developing political milieux. This caused never-ending disputes within the Bulgarian political circles between supporters of a rapprochement with the West and advocates of closer relations with Russia, which, in turn, led not only to numerous political crises, but also implied changes in the highest levels of the government. Only the utmost determination did make it possible for the Bulgarians to overcome internal political problems and to make Bulgaria the leader of other Balkan countries already in the early $19^{\text {th }}$ century. Those complex processes were observed, described and commented upon by Jan Grzegorzewski, and his texts are a perfect source of knowledge both for historians, and other scholars.
\end{abstract}

Translated by Grażyna Waluga

\section{Болгары и Болгария в последней четверти XIX в. в публикациях Яна Гжегожевского (внутренняя и внешняя политика)}

\section{Аннотация}

Период пятисотлетнего турецкого ига болгарских земель вызвало глубокие и многоаспектные перемены почти во всех сферах тамошней общественной жизни. Болгары, столкнутые на обочину и лишенные почти всех публичных прав, были не в состоянии предпринять действия по восстановлению своей элиты, которая была физически или идеологически уничтожена еще во время вторжения турок на Балканы. Из-за чего на пороге обретения независимости болгарский народ имел в распоряжении лишь горстку людей, подготовленных к лидерству и несении государственной службы, как в местном, так и в общегосударственном масштабе. Эта проблема приобрела особенное значение после реактивации болгарской государственности в 1878 г., когда на трудности общественного и экономического характера, скопившиеся перед молодым государством, наложилось тогдашнее соперничество держав за сферы влияний в этой части Европы, которое эффективно поглощало внимание только что создававшихся политических сред. Такое положение вещей приводило в Болгарии к бесконечным спорам между сторонниками сближения с Западом и сторонниками укрепления отношений с Россией, что обернулось не только многочисленными политическими кризисами, но и повлекло за собой изменения в высших эшелонах власти. Лишь необычная решительность в стремлении к национальным целям позволила болгарам не только одолеть внутренние политические 
проблемы, но и уже в начале XX в. сделать свою страну лидером среди других балканских государств. За этими сложными процессами наблюдал, описывал и комментировал Ян Гжегожевский, а его работы являются отличным источником знаний, как для историков, так и для представителей других научных дисциплин.

Перевод Агнешка Поспишиль

\section{Bibliografia}

\section{Źródła i opracowania archiwalne:}

Bilimek-Waissolm H. von, Der bulgarisch-serbisch Krieg 1885, Wien 1886.

Crispi F., Memoiren, Berlin 1912.

Drandar A.G., La Bulgarie sous le prince Ferdinand, 1887-1908, Bruxelles 1909.

Drandar A.G., Les événements politiques en Bulgarie, depuis 1876 jusqu’à nos jours, Bruxelles / Paris 1896.

Forbes N., Toynboe A.J., Mitrany D., Hogarth D.G., The Balkans. A History of Bulgaria, Serbia, Greece, Rumania, Turkey, Oxford 1915.

G[rzegorzewski] J., Dragan Cankow, „Świat Słowiański” 7 (1911), nr 1 (77).

Grzegorzewski J., Rok przewrotów (Bułgarya 1885/86), Lwów 1900.

Grzegorzewski J., Siedmiomiesięczna walka o samoistność Bułgaryi, „Świat Słowiański” 8 (1912), nr 1 (87); nr 1 (88); nr 1 (89).

Grzegorzewski J., Stronnictwa bułgarskie po przewrotach, „Świat Słowiański” 8 (1912), nr 2 (95); nr 2 (96).

Grzegorzewski J., Stronnictwa bułgarskie za Aleksandra Battenberga, „Świat Słowiański” 7 (1911), nr $2(80-81)$.

Huhn A. von, Aus bulgarischer Sturmzeit, Leipzig 1886.

Jankowski C., Na gruzach Turcji. Zarysy historyczno-publicystyczne, Warszawa 1915.

Jireček C., Geschichte der Bulgaren, Prag 1876.

Lipnicki E., Sprawa bułgarska, „Biblioteka Warszawska” 1886, t. 1.

Lipnicki E., Zjazd w Gasteinie i wypadki bułgarskie, „Biblioteka Warszawska” 1886, t. 4.

Mach R. von, Elf Jahre Balkan. Erinnerungen eines preussischen Offiziers aus den Jahren 18761887, [Breslau] 1889.

Malinowski P., Militaryzm współczesny, „Ateneum” 22 (1897), t. 2.

Murzyński K., Serbia i jej przodownictwo, „Niwa” 9 (1880), z. 124.

Piotrowski A., Z dziejów Carstwa Bułgarskiego. Wspomnienia osobiste, „Tygodnik Illustrowany” 42 (1908).

Pług A. [A. Pietkiewicz], Sprawa Bułgarska, „Kłosy” 41 (1885), nr 1059.

Wegnerowicz W.R., Odrodzenie Bułgaryi, „Literatura i Sztuka. Dodatek do Dziennika Poznańskiego" 2 (1913).

Карцов Ю., Семь лет на Ближнем Востоке 1879-1886. Воспоминания политические и личные, Санкт-Петербург 1906.

Радев С., Строителите на съвременна България, т. 1-2, София 1911.

Станев Н., История на нова България 1878-1928, София 1929. 


\section{Opracowania:}

Rubacha J., Bułgarzy i Bułgaria w ostatniej ćwierci wieku XIX w publikacjach Jana Grzegorzewskiego (kultura, ludność, gospodarka), „Studia z Dziejów Rosji i Europy Południowo-Wschodniej” 51 (2016), z. 1, s. 23-48.

Rubacha J., Malinowski A., Giza A., Historia Bułgarii 1870-1915. Materiały źródłowe z komentarzami, t. 1: Polityka międzynarodowa, Warszawa 2006.

Rubacha J., Malinowski A., Historia Bułgarii 1870-1915. Materiały źródłowe z komentarzami, t. 3: Polityka wewnętrzna, Warszawa 2009.

Wituch T., Tureckie przemiany. Dzieje Turcji 1878-1923, Warszawa 1980.

Външната политика на България. Документи и материали, ред. Д. Косев, т. 1-2, София 1978.

Грънчаров С., Русофилските политически сили в България (август 1886-август 1887 г.), „Известия на Института за история” 26 (1983).

Маринов Д., Стебан Стамболов и новейшата ни история, т. 1-2, София 1992.

Програми, програмни документи и устави на буржоазните партии в България 1879-1918, съст. В. Николова, Д. Саздов, София 1992.

Сръбско-българската война 1885. Сборник документи, съст. Е. Харбова, Л. Цветкова, С. Шанов, София 1985.

Стателова Е., Дипломация на Княжество България 1879-1886, София 1979.

Стателова Е., Попов Р., Танкова В., История на българската дипломация 1879-1913 г., София 1994.

Цураков А., Правителствата на България, ч. 1, София 1996.

Jarosław Rubacha, dr hab., historyk, bałkanista, pracownik Instytutu Dziennikarstwa i Komunikacji Społecznej Uniwersytetu Warmińsko-Mazurskiego w Olsztynie; zajmuje się historią Półwyspu Bałkańskiego w XIX i XX w., historią Bułgarii i polskim słowianofilstwem na początku XX stulecia (j.rubacha@wp.pl).

Jarosław Rubacha, holder of a post-doctoral degree, historian of the Balkans; his research interests focus on: the history of the Balkan Peninsula in the 19th and 20th cc., history of Bulgaria and Polish Slavophilia in the early $20^{\text {th }}$ c. (j.rubacha@wp.pl). 